\title{
Incentivizing Calculated Risk-Taking: Evidence from an Experiment with Commercial Bank Loan Officers
}

\section{Citation}

Cole, Shawn, Martin Kanz, and Leora Klapper. "Incentivizing Calculated Risk-Taking: Evidence from an Experiment with Commercial Bank Loan Officers." Harvard Business School Working Paper, No. 13-002, July 2012.

\section{Permanent link}

http://nrs.harvard.edu/urn-3:HUL.InstRepos:9369407

\section{Terms of Use}

This article was downloaded from Harvard University's DASH repository, and is made available under the terms and conditions applicable to Open Access Policy Articles, as set forth at http:// nrs.harvard.edu/urn-3:HUL.InstRepos:dash.current.terms-of-use\#OAP

\section{Share Your Story}

The Harvard community has made this article openly available. Please share how this access benefits you. Submit a story. 
H A R VARD D B U S I N E S S S C H O O L

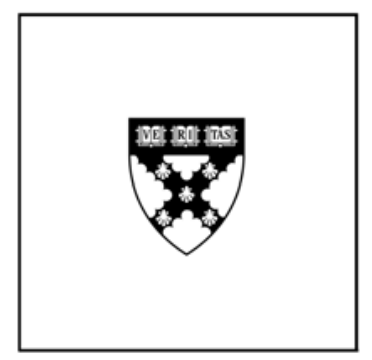

\section{Incentivizing Calculated Risk-Taking: Evidence from an Experiment with Commercial Bank Loan Officers}

Shawn Cole

Martin Kanz

Leora Klapper

\section{Working Paper}

13-002

July 5, 2012 


\title{
Incentivizing Calculated Risk-Taking: Evidence from an Experiment with Commercial Bank Loan Officers
}

\author{
Shawn Cole, Martin Kanz, and Leora Klapper*
}

July 5, 2012

\begin{abstract}
This paper uses a series of experiments with commercial bank loan officers to test the effect of performance incentives on risk-assessment and lending decisions. We first show that, while high-powered incentives lead to greater screening effort and more profitable lending, their power is muted by both deferred compensation and the limited liability typically enjoyed by credit officers. Second, we present direct evidence that incentive contracts distort judgment and beliefs, even among trained professionals with many years of experience. Loans evaluated under more permissive incentive schemes are rated significantly less risky than the same loans evaluated under pay-for-performance.
\end{abstract}

JEL: D03, G21 J22, J33, L2

Keywords: loan officer incentives, banking, emerging markets

\footnotetext{
*Harvard Business School; World Bank; and World Bank, respectively. E-mails: scole@hbs.edu, mkanz@worldbank.org, and lklapper@worldbank.org. We wish to thank the cooperating financial institution for providing us with the data on loan applications used in this paper. For helpful comments and suggestions, we thank Philippe Aghion, Andreas Fuster, Victoria Ivashina, Raj Iyer, Michael Kremer, Rohini Pande, Jose Liberti, Daniel Paravisini, Enrichetta Ravina, Andrei Shleifer, Antoinette Schoar, Erik Stafford, Jeremy Stein, and conference and seminar participants at Bocconi (Carefin), University of Chicago (Advances with Field Experiments), IGIDR Mumbai, IIM Bangalore, FIRS (Minneapolis), LBS European Winter Finance Conference 2012, NBER Corporate Finance, NBER Risks of Financial Institutions, University of Virginia (Darden), and the World Bank. Samantha Bastian, Doug Randall, and Wentao Xiong provided excellent research assistance. Financial assistance from the Kauffman Foundation, the International Growth Center, and the Harvard Business School Division of Faculty Support and Research, is gratefully acknowledged.The opinions expressed do not necessarily represent the views of the World Bank, its Executive Directors, or the countries they represent.
} 
"An evaluation of compensation practices at banking organizations preceding the financial crisis reveals that they did, in fact, contribute to safety and soundness problems. Some firms gave loan officers incentives to write a lot of loans, without sufficient regard for the risks associated with those activities. The revenues that served as the basis for calculating bonuses were generated immediately, while the risks might not have been realized for months or years [...]. When these or similarly misaligned incentive compensation arrangements were common in a firm, the very foundation of sound risk management could be undermined by the actions of employees seeking to maximize their own pay."

-Daniel Tarullo, Board of Governors of the United States Federal Reserve ${ }^{1}$

\section{Introduction}

Following the global financial crisis, bank compensation has come under increased scrutiny. While much of this attention has focused on incentives for top management, there is growing recognition that non-equity incentives (such as commissions) provided to loan originators and risk managers, may share some of the blame. Indeed, providing appropriate performance incentives to employees at the lower tiers of a commercial bank's corporate hierarchy is a difficult problem: their very responsibility is to collect information that the bank cannot otherwise observe, making monitoring difficult; they enjoy limited liability, and may have different risk and time preferences than the bank's shareholders.

This paper presents direct evidence on the effect of incentives on lending decisions and risk-assessment. In a series of experiments, loan officers were paid to review and assess actual loan applications, making over 14,000 lending decisions under exogenously assigned incentive contracts. We evaluate three important classes of incentive schemes: (i) volume incentives that reward origination, (ii) low-powered incentives that reward origination conditional on performance, and (iii) high-powered incentives that reward performance and penalize default.

Our first set of results document the efficacy and limitations of performance incentives in lending. We provide evidence that the structure of performance incentives strongly af-

\footnotetext{
${ }^{1}$ In a speech entitled "Incentive Compensation, Risk Management, and Safety and Soundness" at the University of Maryland Robert H. Smith School of Business. Washington, D.C., November 2, 2009.
} 
fects screening effort, risk-assessment, and the profitability of originated loans. Loan officers who are incentivized based on lending volume rather than the quality of their loan portfolio originate more loans of lower average quality. By contrast, high-powered incentives that reward loan performance and penalize bad lending decisions cause loan officers to exert greater screening effort, reduce exposure to loans with higher perceived ex-ante credit risk, and induce significantly more profitable lending decisions while leading only to a small reduction in lending volume. Relative to a baseline treatment with low-powered incentives, high-powered incentives increase the probability that a bad loan is detected and increase profits per originated loan by up to $3.5 \%$ of the median loan size; in contrast, origination incentives lead to a substantial decline in the quality of originated loans and reduce profits per loan by up to $5 \%$ of the median loan size.

Building on these results, we explore a number of constraints, inherent to any incentive contract in lending, that may limit the efficacy of pay for performance. Consistent with the predictions of a simple model of loan officer decision-making, we find that deferred compensation attenuates the effectiveness of high-powered incentives. When incentive payments are awarded with a three month delay, our measures of costly screening effort decline by between $5 \%$ and $14 \%$, and we document a corresponding but less pronounced decline in the quality of originated loans. Notably, we find that deferred compensation also moderates the negative effect of incentive schemes that emphasize loan origination over the quality of originated loans. Relaxing loan officers' limited liability constraint (similar in spirit to giving a loan officer equity in the loan) induces greater screening effort and leads to more conservative lending decisions, but has only a moderate effect on the profitability of originated loans.

In our second set of results, we demonstrate that performance incentives also have important effects on the subjective perception of credit risk. We find that loan officers evaluating applications under performance contracts that provide strong incentives for approval systematically inflate internal ratings they assign to the loans they process. While internal ratings 
are strongly predictive of default under all incentive schemes, loan officers facing volume incentives inflate risk ratings by as much as .3 standard deviations and irrespective of the underlying asset quality. Loan officers inflate all features of the credit evaluation, including measures that are difficult to quantify, such as the character of the borrower, as well as metrics based on harder information such as interest coverage ratios. Since incentives affect both risk ratings and approvals, the loan book approved under a permissive incentive scheme may therefore be of poorer quality but, based on internal ratings alone, may in fact look less risky than a set of comparable loans approved under a more conservative incentive scheme.

The use of actual loan applications, evaluated by experienced loan officers, allows us to identify the impact of performance incentives on risk-assessment and actual risk-taking. By design, our experimental set-up focuses on the lending decision, and allows us to isolate the impact of performance pay on the quality of the initial screening decision from other channels through which incentives may affect loan performance, such as the collection of soft information or the degree of ex-post monitoring. ${ }^{2}$

This paper contributes to several literatures. The importance of incentives within the firm has long been appreciated (see Baker, Jensen and Murphy (1988) for a review), ${ }^{3}$ yet most empirical work that credibly identifies exogenous variation in performance incentives has focused on relatively simple production tasks (see Lazear (2000); Bandiera, Barankay and Rasul (2007, 2009, 2011); Kremer, Kaur and Mullainathan (2010)). We extend this literature

\footnotetext{
${ }^{2}$ While client acquisition and monitoring are clearly important, the focus of our experiment is on the impact of performance pay on screening incentives (for related evidence on screening incentives in sub-prime and small-enterprise lending, see Keys, Mukherjee, Seru and Vig (2010) and Agarwal and Ben-David (2012)). The experimental approach we pursue in this paper allows us to isolate the impact of performance pay on screening behavior from other factors influencing loan origination and performance, such as information production (Stein, 2002) and ex-post monitoring (Petersen and Rajan, 1994a). This distinction is also motivated by the fact that in the lending environment we study, the three stages of the lending process (collection of infomation and assembling information in the loan file, making a lending decision based on this information and monitoring originated loans) are carried out by different employees, each facing their own wage schedule.

${ }^{3}$ For evidence on team incentives, see Nalbantian and Schotter (1997) and Bandiera, Barankay and Rasul (2011), for more on rank order based incentives see Lazear and Rosen (1981).
} 
by focusing on a complex task in which unobservable effort is of paramount importance, and where performance pay may affect productivity through a direct incentive effect as well as a variety of behavioral channels, such as its impact on the subjective perception of credit risk.

Second, and relatedly, we contribute to the literature on incentive compensation and risk-taking. The existing evidence in this area has focused almost exclusively on risk-taking among CEOs and top executives (see, for example, Bebchuk and Spamann (2010), Bolton, Mehran and Shapiro (2010), Edmans and Liu (2011) and Fahlenbach and Stulz (2012)). ${ }^{4}$ Balachandran, Kogut and Harnal (2011), for instance, show that during the recent financial crisis, the prevalence of equity-based executive compensation at banks was associated with a higher probability of the bank's default. Mechanisms similar in their effect to equity compensation have been proposed to align the incentives of employees at lower levels of a bank's hierarchy with those of the bank.

A growing literature highlights the importance of incentives for the production and transmission of information for risk-management in commercial lending. Hertzberg, Liberti and Paravisini (2010) demonstrate the presence of moral hazard in information revelation in an Argentinian bank. Liberti and Mian (2009) show that hierarchical separation between loan officers and their supervisors leads to greater reliance on hard information. Qian, Strahan and Yang (2011) study the incentive effects of a policy reform in China that increased the accountability of loan officers at state banks. They show that this non-pecuniary change in loan officer incentives led to a significant improvement in the assessment of credit risk. Using data from a large European bank, Berg, Puri and Rocholl (2012) show that in a setting where loan approvals are based entirely on hard information, incentives that reward lending volume lead loan officers to strategically manipulate applicant information for borrowers close to the bank's minimum threshold for approval. Finally, and most directly related to our study,

\footnotetext{
${ }^{4}$ For more on performance pay among CEOs and top executives, see Jensen and Murphy (1990), Murphy (1998) and Margiotta and Miller (2002). For a review and discussion of bank incentives in the context of sub-prime lending, see also Bebchuk and Spamann (2010), Bebchuk et al. (2010) and Rajan (2010).
} 
Agarwal and Wang (2009) and Agarwal and Ben-David (2012) exploit an exogenous change in the compensation structure of a bank in the United States to show that volume incentives encourage excessive risk-taking and increase defaults.

The findings we report in this paper make the following three main contributions. First, existing evidence on the effect of performance incentives in lending is limited to incentive systems with relatively apparent flaws (such as an origination bonus). By contrast, our experimental design allows us to test a range of incentive arrangements, including those which are closer to an optimal contract. We offer the first empirical measurement and quantification of two important constraints that prevent first-best contracting in a lending setting: deferred compensation and limited liability. Additionally, our experimental design tracks aspects of loan officer behavior that would normally be unobservable to a bank or econometrician, and allows for the direct measurement of the relationship between incentives, effort, and loan performance.

Second, we present new evidence that performance incentives can distort the assessment of credit risk, even when internal ratings are not tied to loan officer compensation. The finding that loan officers change their assessment of credit risk in response to monetary incentives is consistent with the psychological concept of cognitive dissonance (Akerlof and Dickens, 1982) and resonates with stylized evidence from sub-prime lending (Barberis, 2012): loan officers manipulate their beliefs about loans they review because they are not comfortable thinking that the loans they wish to approve under prevailing incentives are indeed of poor quality. This "wishful thinking" effect is also similar to the one identified by Moore, Tanlu and Bazerman (2003) and Mayraz (2012) in laboratory experiments in which participants assigned to the role of the buyer in a fictitious market reported lower private valuations and predictions of future asset prices than those assigned to the role of the seller.

Finally, this paper contributes to the literature on lending in informationally opaque credit markets. We examine the role of loan officer effort and risk-assessment in an envi- 
ronment of high idiosyncratic risk. This is related to, but distinct from, the special role played by loan officers in collecting soft information, and monitoring borrowers following the disbursal of a loan (see Petersen and Rajan (1994b), Berger and Udell (1995), and Berger, Klapper and Udell (2001) $)^{5}$. The separation of information collection and approval decisions is common for a wide range of financial products, and is especially relevant in emerging markets for two reasons. First, the small ticket size of consumer and small-enterprise loans in these markets typically rules out the use of a costly, relationship-intensive lending model so that the collection of customer information for small-ticket loans is often outsourced to third parties. Second, regulation often constrains the degree of decentralization of foreign lenders (see Mian (2006)). This further limits the use of relationship lending, especially for smaller loans, and places greater importance on risk-management at the time of the initial screening decision, which is the focus of our analysis in this paper.

The remainder of the paper proceeds as follows. In the next two Sections we discuss the basic incentive problem, and describe the incentive schemes we test and how they relate to a simple theoretical model of loan officer decision makig. Section 3 describes our experimental set-up, and section 4 presents our main results. Section 5 concludes.

\section{Performance Incentives in Lending}

The potential for excessive and socially inefficient risk-taking in response to poorly designed incentive schemes has long been recognized. However, first-best incentive contracts may not be implementable in many real world settings. Pay for performance schemes require easily quantifiable criteria against which to measure and reward performance, which may be difficult or impossible to define for complex tasks, such as loan origination. In many organizational settings, the implementation of optimal incentive contracts is further constrained by multi-

\footnotetext{
${ }^{5}$ For more empirical evidence on lending relationships see also Harhoff and Korting (1998) and Santikian (2011). For a survey of the literature on relationship lending see Boot (2000).
} 
tasking concerns, the difficulty in observing effort, and the tradeoff between the desire to balance incentives and insurance against negative outcomes. ${ }^{6}$

The basic incentive problem in lending arises from the fact that loan officers are tasked with allocating the bank's capital based on private information and risk-assessments that are usually unobservable to the bank (Udell (1989), Berger and Udell (2002), Stein (2002)). In this setting, several important constraints preclude the implementation of a contract that would align the incentives of the bank's shareholders with those of its employees by making a loan officer the fully liable residual claimant of the loan.

First, loan officer effort is typically unobservable to the bank. Second, loan officers are by necessity protected by limited liability, since they take decisions on large amounts of money, which typically far exceed the amount of any penalty a bank could enforce to penalize bad lending decisions. Third, loan officers may have a different time horizon and a higher discount rate than the bank. It may therefore be more expensive to generate effort with deferred pay, and pay that is conditioned on loan outcomes, than with an immediate performance bonus. Finally, in contrast to production tasks with a clear relationship between input and outcome, the assessment of credit involves a complex tradeoff between risk and return in an environment with high aggregate and idiosyncratic risk. This makes it difficult to reliably identify idiosyncratic defaults and further complicates the use of (noisy) realized outcomes as a benchmark for the measurement of loan officer effort and performance.

While these constraints are present in any lending environment, they are likely to bind much more severely in emerging credit markets, characterized by severe information asymmetries, limited credit information and poor enforceability of debt contracts. Banks in this environment are thus particularly reliant on the risk-assessment of their front-line employees, which in turn introduces significant scope for moral hazard and agency conflict within the lending institution (see, for example, Liberti (2005), Liberti and Mian (2009)).

\footnotetext{
${ }^{6}$ See Gibbons (1998) for a review.
} 
Where banks provide performance incentives, loan officer compensation usually consists of a fixed base salary and a performance component. This performance component may place weight on lending volume, ex-post loan performance, or a combination of the two. ${ }^{7}$ The recent debate on bank compensation has focused on two key features of such incentive contracts in lending: First, the incentive power of the contract, which affects how sensitive loan officers are to the costs of default; and the often short time-horizon of compensation, which may lead loan officers to focus on short-term gains rather than long-term value. In the experiments reported in this paper we vary both dimensions, and demonstrate that both have important implications for risk-assessment and lending decisions in a sample of highlyexperienced loan officers. ${ }^{8}$ In addition, we provide novel evidence on behavioral effects that may limit the efficacy of loan officer incentives as a tool for managing credit risk.

As a framework for the empirical analysis, we develop in the appendix a simple model of performance incentives and loan officer decision-making. In the model, a loan officer may exert costly effort to obtain a signal about the quality of a proposed loan. The model makes four simple predictions about the effect of performance incentives on loan officer behavior. First, an origination bonus scheme as often employed by commercial banks, which incentivized lending volume without penalizing default leads to indiscriminate lending, low effort and high defaults. By contrast, high-powered incentives that reward profitable decisions and penalize default result in greater screening effort but more conservative lending decisions. Second, deferring compensation reduces the power of performance-based incentives. Third, relaxing a loan officer's limited liability constraint increases effort. Finally, intrinsically motivated loan officers exert more effort.

\footnotetext{
${ }^{7}$ In many cases, the contract also includes a team performance component. To limit multi-tasking concerns, our experiments focus on changes to the individual performance component of the contract.

${ }^{8}$ Heider and Inderst (2011) develop a model relating the choice of loan officer incentives to the severity of the bank's internal agency problem which is in turn determined by the banks' competitive position. In our experiments, we abstract from the bank's optimal choice of incentive scheme and focus on the loan officer's (behavioral) response to a menu of commonly implemented incentive contracts.
} 
In the empirical section of this paper, we take these predictions to the data and additionally study the effect of performance incentives on loan officers perception of credit risk. We find that volume incentives lead loan officers to inflate internal ratings, even when these ratings are not tied to the loan officer's evaluation or incentive scheme, while high-powered incentive contracts lead to a more accurate assessment of credit risk and more profitable lending decisions.

\section{Experimental Incentive Schemes}

We test the predictions of the model (see appendix) using a framed field experiment, in which commercial bank loan officers evaluate loan applications from the client database of a large Indian bank. To test the impact of performance contracts on loan officer behavior, we exogenously vary the incentive power, the time horizon over which performance incentives are paid, and the degree of limited liability enjoyed by a loan officer. We vary the power of the incentive contract by assigning loan officers to contracts that specify three conditional payments: a payment $w_{P}$ made when a loan is approved and performs, a payment $w_{D}$, made when a loan is approved and defaults and a payment $\bar{w}$ that is made when a loan is declined.

Because the outcome of a loan is only observed with some delay, performance incentives, in practice, must be paid with a lag. In our setting, under the non-deferred payment scheme, incentives were paid immediately following an experimental session. In the deferred compensation scheme, incentive payments were delayed three months, with the loan officers given a choice of returning to collect the payment, or receiving a check in the mail. This allows for two contrasts: from the policy perspective, comparing deferred-compensation, performance based pay to immediate compensation based on origination.

Finally, we experimentally relax loan officers' limited liability constraint, by providing an initial endowment that the participant can lose if he approves a number of non-performing 
loans. This mimics proposed "clawback" schemes. Throughout the paper, we express experimental incentive contracts as as the vector $\mathbf{w}=\left[w_{P}, w_{D}, \bar{w}\right]$. In addition to these three performance-based conditional payments, loan officers received an unconditional show-up fee of Rs 100 (US\$ 2.25), each time they participated in a session of the experiment. To ensure that participants perceived conditional payoffs as salient, we calibrated the mean payout of experimental incentive schemes to roughly 1.5 times the hourly wage of the median participant in our experiment, a Level II public sector credit officer with an annual income of Rs 240,000 (US\$4,800) and an approximate hourly wage of Rs 125 (US\$2.5).

Because understanding the impact of monetary incentives on (costly) screening effort was a main objective of the experiment, half of our sessions included a "costly information" feature. In this condition, loan officers were given an initial information endowment of Rs 108. In the "costly information" setting, loan officers were able to review only basic client and loan information items for free (two out of nine sections of the loan application) and were charged Rs 3 per section for as many of the remaining loan file sections as they chose to view. In these sessions, loan officers received their remaining information endowment in cash at the conclusion of the session, in addition to their incentive payments.

Table I summarizes the experimental incentive schemes. An obvious feature of incentive schemes $\mathrm{C}$ is that a (weakly) dominant strategy from the participants perspective is to exert no effort screening, and accept every loan application. This corresponds to a volume "origination piece rate" often observed in consumer lending. In addition to these schemes, the research staff ran two additional schemes which do not mimic real-world schemes. Scheme $\mathrm{D}$ paid Rs 50 if a loan performed, and zero if it defaulted or was rejected. Scheme E paid Rs 100 (US\$ 2.25) if a loan performed, and 0 if it defaulted or rejected. As these schemes do not have real-world counterparts, and were run on a reduced sample, we do not focus on them in this paper. However, complete results are reported in the supplementary appendix.

We test the following predictions. First, incentives awarded for origination will lead 
to excessive risk-taking. Indeed, purely rational and profit-maximizing loan officers should indiscriminately approve all applications under scheme C, and exert no screening effort. Second, high-powered incentives will increase effort by increasing the rewards for a profitable lending decision and increasing the penalty for originating a loan that ultimately becomes delinquent. Thus, the amount of effort exerted under various treatment can be ranked B $>\mathrm{A}>\mathrm{C}$. Third, high-powered incentives will induce more conservative lending behavior by increasing the cost to the loan officer of making a bad lending decision. Fourth, if a loan officer's discount rate is greater than zero, the amount of effort induced by deferred compensation will be less than the amount of effort induced by A and B. Finally, if credit officers are intrinsically motivated, or believe that their performance on this task may affect their reputation, they may invest in screening loan applications even when such scrutiny will not yield additional remuneration.

\section{Experimental Context and Design}

\subsection{Experimental Task}

The experiment is designed to closely match the lending process for low-documentation small business loans, a class of loans for which the accurate assessment of credit risk depends crucially on the judgment of the bank's loan officers. Loan officers recruited from leading Indian commercial banks visit our labs outside of work hours to evaluate credit applications. The credit application files were obtained from a leading commercial lender in India, and are described below. Participants evaluate these applications, complete a risk evaluation form, and make a recommendation about whether the loan should be approved.

While the lending decisions are hypothetical, in the sense that loans underlying the

experiment have been previously made and their outcome is observed, participants receive 
only information that was available to the bank at the original time of application. Because we observe the performance of loans in our data set, we can pay participants performance incentives based on their decision and the actual outcome of the loan. Our sample of loans consists of unsecured small-business working capital loans with a ticket size of less than Rs 500,000 (US\$ 10,000). Sales and origination channels for this class of loans are generally distinct, so that (analogous to low-documentation loans in the United States) loans are sourced by a bank's sales agents who collect client information, which is then forwarded to a credit officer for approval. The task faced by the bank's credit officers is to screen and make profitable lending decisions based on the information contained in an applicant's loan file.

The applicant information contained in the loan files is "hard" in the sense that it can be transcribed. However, borrower information differs in its degree of verifiability, and ranges from audited financials to information that requires a significant degree of interpretation, such as trade reference reports or a description of the applicant's business (see Petersen (2004) for a discussion). Although regulators require banks to collect an applicant's tax record and audited income statement, this information is often unreliable and difficult to verify. New applicants typically lack a credit score or established record of formal borrowing, which rules out the use of predictive credit scoring, "scorecard lending" and other more systematic loan approval technologies. Because the ticket size of a representative small business loan is small, relative to the fixed cost of underwriting, risk-management occurs primarily through ex-ante screening, rather than prohibitively costly relationship lending or ex-post monitoring.

\subsection{Loan Database}

As a basis for the experiment, we requested a random sample of loan applications from a large commercial lender in India (hereafter "the Lender"), and received 650 loan files. The loan files contain all information available to the Lender at the time the application was processed, as 
well as at least nine months of repayment history for each loan ${ }^{9}$. The information contained in each loan application can be grouped into the following categories, corresponding to the sections of the Lender's standard application format: (1) basic client information including a detailed description of the client's business, (2) documents and verification (3) balance sheet and (4) income statement. In addition, participants in the experiment had access to three types of background checks for each applicant: (5) a site visit report on the applicant's business, (6) a site visit report on the applicant's residence and (7) a credit bureau report, available for $66 \%$ of all applicants. We limit our attention to uncollateralized small business loans to self-employed individuals, with a ticket size between Rs 150,000 (US\$ 3,000) and Rs 500,000 (US\$ 10,000). ${ }^{10}$ Loan file summary statistics are reported in Table III. We consider only term loans to new borrowers, many of whom are first-time applicants for a formal sector loan. ${ }^{11}$ The median loan in our database has a tenure of 36 months, a ticket size of Rs 283,214 (US\$ 6,383) and a monthly installment of Rs 9,228. (US\$208).

To rule out vintage effects and ensure consistency in the initial screening standards applied to loans used in the experiment, we restrict our sample to loans originated in 2009 Q1 and 2009 Q2. Based on the Lender's proprietary data on the repayment history of each loan, we then classified credit files into performing and non-performing loans. Following the standard definition, we classify a loan as delinquent if it has missed two monthly payments and remains 60+ days overdue, and as performing otherwise. To calculate profitability to

\footnotetext{
${ }^{9}$ More than $90 \%$ of all defaults occur during the first five months of a loan's tenure, so that our default measure allows for a relatively precise measurement of loan quality.

${ }^{10}$ While none of the loans in the experiment carried any collateral security, borrowers faced strong incentives for repayment. First, the Lender routinely offers follow-up loans at reduced interest rates to clients with a good repayment history. Second, borrowers who default on their loans are reported to India's main credit bureau, implying a credible threat of future exclusion from bank credit. Loans that remain unsettled for $90+$ days are classified as non-performing (NPA), reported to the credit bureau, and referred to the Lender's collections department. A small fraction of loans in the overdue category are restructured in negotiation between clients and the Lender. To rule out selection bias, our sample excludes repeat borrowers and restructured loans.

${ }^{11}$ Since none of the loans in our sample are collateralized, they are priced at an annual interest rate of between 15 and 30 per cent. We control for the variation in interest rates by including loan fixed effects.
} 
the bank, we subtract the disbursal amount from the discounted stream of repayments. ${ }^{12}$ To achieve as representative a sample as possible, we also include 26 credit files from clients who applied, but were turned down by the Lender. For the incentive payouts in our study, these rejected loans are treated as non-performing ${ }^{13}$. Throughout the analysis, we report results disaggregated by non-performing and declined loans and show that our results are unaffected by the classification of loans declined ex-ante by the Lender. Importantly, the final columns of Table III show that loan files contain information that may be useful in distinguishing good loans and bad loans, suggesting there are returns to effort in this setting.

\subsection{Loan Officers and Experimental Procedure}

Loan officers were recruited from the active staff of several leading private and public sector commercial banks. Participants first attended an introductory presentation, completed a practice session, and then participated in up to 15 sessions of the experiment, in which they evaluated six loan applications per session. Working conditions and presentation of information were designed to closely resemble the actual work environment of the representative loan officer. ${ }^{14}$ Experimental sessions were scheduled to last one hour, although participants could finish early or late if they so chose. Incentive treatments, as described in Section 2, were randomly and individually assigned at the loan officer and session level, such that officers evaluated a batch of six loans under a given scheme. ${ }^{15}$ The experiments took over a year to complete, and not all incentive schemes were eligible to be assigned in any given session.

\footnotetext{
${ }^{12}$ We estimate the Lender's net profit per loan as the net present value of the disbursal plus repayments including interest, discounted by $8 \%$, the approximate rate on Indian commercial paper between January 1 and December 31, 2009, and assuming a $10 \%$ recovery on defaulted loans.

${ }^{13}$ However, we do not include initially rejected loans in the profitability calculations. In non-reported results we also verified that our analysis is robust to the exclusion of rejected loans.

${ }^{14}$ Harrison, List and Towe (2007) point out that laboratory behavior may not match field behavior when eliciting risk attitudes ("background risk"). In contrast to that study, we use within-subject variation, and the inclusion of loan officer fixed-effects may reduce the importance of heterogeneous perceptions of background risk from different subjects.

${ }^{15}$ The number of loan files was held constant to rule out multitasking concerns.
} 
Hence, our regressions include a set of fixed effects to control for these randomization strata.

At the start of each session, loan officers were assigned to an incentive treatment, received a one-on-one introduction to the incentive scheme and completed a short questionnaire to verify comprehension. We report summary statistics for the population of participating loan officers in Table II, Columns (1) to (4). The median loan officer in our sample is a Level II public sector bank employee who is 35 years old, and has 10 years of work experience. In Table II, Columns (5) to (8) we report comparable characteristics from a sample of all loan officers from a major bank in the state in which our experiment takes place. Our sample is quite representative of this reference population in terms of age, rank and experience.

A customized software interface reproduced each section of the loan application on a separate tab: a description of the applicant's business, balance sheet, trade reference, site visit report, document verification and credit bureau report when available. While reviewing this information, participants were asked to assess the applicant's credit risk using a form adapted from the standard format of a leading Indian commercial bank, with categories for personal risk, business risk, management risk and financial risk. The risk ratings serve three purposes: first, they add realism to the lab session, as completing an internal risk rating is a routine part of evaluating applications; second, they allow us to elicit a measure of perceived credit risk that is not tied to loan officer compensation. Finally, internal ratings serve to assist the loan officer in aggregating information about the application in a systematic way. Within each experimental session, the sequence of loan files was randomly assigned, but the ratio of performing, non-performing and declined loans was held constant at four performing loans, one non-performing loan and one loan declined by the Lender. ${ }^{16}$ Loan officers were asked to evaluate these loans based on their best judgment, but were not given information about the ratio of good and bad loans or the outcome of any particular loan under evaluation.

\footnotetext{
${ }^{16}$ We chose this ratio to match responses to a pilot survey, in which we elicited the expected distribution of performing, non-performing and ex-ante declined loans for loans of the type used in the experiment.
} 


\section{$5 \quad$ Empirical Strategy and Results}

Since treatment status was randomly assigned, our empirical strategy is straightforward and we estimate treatment regressions of the form:

$$
y_{i l}=\sum_{k=1}^{K-1} \beta_{k} \mathrm{~T}_{i l k}+\theta_{i}+\theta_{l}+\zeta^{\prime} \mathbf{R}_{i l}+\xi^{\prime} \mathbf{X}_{i l}+\varepsilon_{i l}
$$

where $y_{i l}$ is the outcome of interest for loan officer $i$ and loan $l, T_{i l}$ is a vector of treatment dummies for the incentive schemes being compared to the baseline. In all regressions, we use the low-powered baseline incentive $\mathbf{w}_{\mathrm{B}}=[20,0,10]$ as the omitted category. We additionally control for loan officer fixed effects, $\theta_{i}$, loan file fixed effects $\theta_{l}$, and individual controls $\mathbf{X}_{i l}$, including loan officer age, seniority, rank, education, and include dummies for whether the loan officer has management and business experience. Finally, we include dummies for the randomization strata, $\mathbf{R}_{i l}$. Standard errors are clustered at the loan officer-session level, ${ }^{17}$ the same level at which the treatment is assigned.

Our data set includes 14,369 lending decisions, representing 206 unique subjects, with three key treatment conditions: (1) Low-powered incentives, which we use as the baseline throughout the empirical analysis; (2) High-powered incentives, which reward loan officers for approving loans that perform and penalizes the origination of loans that default; and (3) Origination bonus, which rewards the loan officer for every originated loan. ${ }^{18}$

In addition to these incentive vectors, we vary conditions under which incentives are paid. In 369 randomly selected sessions (2,214 loan evaluations), we defer incentive payments by 3 months, rather than paying immediately. In further 163 sessions (978 evaluations), we relax the participant's limited liability constraint by providing an initial information endowment of Rs 200 (US\$4.5), which can be lost if a loan officer makes a series of unprofitable lending

\footnotetext{
${ }^{17}$ Each session consists of one loan officer evaluating six files.

${ }^{18}$ Regressions using all data we collected, which includes the performance bonus schemes which pay only if a loan performs, along with the appropriate treatment dummies, are reported in the supplementary appendix.
} 
decisions. Finally, in 137 sessions (3,638 loans), we provide loan officers with an initial information endowment of Rs 108 (US\$2.25), which they may spend to sections of the loan file. Table I summarizes the sample sizes used for contrasts. Table OA.I in the supplementary appendix reports a test of random assignment that compares loan officer characteristics across treatments, and confirms that the randomization was successful.

To test our hypotheses, we consider three groups of outcomes: (i) measures of screening effort, (ii) measures of subjective risk-assessment, and (iii) lending decisions (actual risktaking) and the resulting profitability of originated loans. We construct two measures of screening effort: the number of credit file sections reviewed by a credit officer; and the amount of money spent on reviewing additional information under the costly-information treatment. To measure risk-assessment and risk-taking, we record internal risk ratings assigned to each loan. Finally, to evaluate loan officer decisions and performance, we match the loan officer's lending decision to the actual profitability of the loan to the financial institution.

\subsection{Descriptive Statistics}

Before turning to the main analysis, we report descriptive statistics of loan evaluations during the exercise. We first verify that the experimental task is meaningful, in the sense that it is indeed possible for loan officers to infer credit risk based on hard information contained in an applicant's loan file. To do this, Table III presents mean comparisons of loan application information for performing and non-performing loans. As is evident from the test statistics comparing hard information characteristics of performing and non-performing loans, there are a number of systematic differences in these loan characteristics that help distinguish ex-post profitable from ex-post defaulting loans. In particular, borrowers who defaulted on their loans had substantially lower revenue, younger businesses, higher ratios of monthly debt service to income, compared to borrowers who remained current on their obligations. 
Overdues on credit reports also predicted default. Higher-quality borrowers did report higher levels of debt, a fact consistent with the common observation of low-quality borrowers being excluded from formal financial markets.

Table IV reports summary statistics of loan evaluations by loan type and incentive. We note the following. First, even for a group of highly experienced loan officers, making profitable lending decisions in this informationally challenging lending environment was not a trivial task. On average, loan officers approved $75 \%$ of all loans evaluated in the experiment and made correct lending decisions in $65 \%$ of all cases. Lending decisions were, however, profitable under all incentive schemes in the experiment and would have earned the bank an average net present value of US\$240 (5.9\% of the median loan size) per originated loan. Lending volume responds dramatically to incentives. Identifying performing loans was substantially easier than identifying non-performing loans or loans that were rejected by the Lender ex-ante. Changes in the incentive power of the contract were especially effective in improving loan officer's success in detecting non-performing loans (Column (9)). These patterns are directly reflected in the profitability of loans approved under alternative incentive schemes (Column (6)).

Table IV Column (2) describes the number of sections a loan officer reviewed prior to making a decision, while Column (3) gives this number for only the subsample which was charged to see additional sections from the loan file. Virtually all loan officers study the basic information and borrower profile sections. However, some chose to reject or accept a loan prior to viewing the entire application, particularly when the incentive scheme did not reward higher-quality screening. When information was costly, loan officers were most likely to pay for income statements and balance sheet information, and much less likely to pay for the site visit reports (results not reported in table).

In addition to observed lending decisions, we analyze loan officer risk assessment, as measured by the rating each loan officer gave to each loan. Since these ratings themselves 
were not incentivized, one might be concerned about whether they contain useful information. We report formal tests of the information content of internal ratings in Table OA.III in the supplementary appendix. The results show that loan officer assessments of credit risk are a meaningful and strongly significant predictor of actual lending decisions, the probability of default and the profit of loans evaluated in the experiment. This is true for the overall rating (Table OA.III, Panel A) as well as its sub-components measuring an applicant's perceived personal and financial risk (Table OA.III, Panel B and C). A Kolgomorov-Smirnov test of the equality of ratings for performing versus non-performing loans rejects at the $1 \%$ level.

Since loan officers complete multiple sessions, one might wonder whether loan officers learn over the course of the study. An affirmative answer might be cause for concern, given that our average loan officer has over 13 years of experience lending. To verify that learning over the course of the exercise poses no threat to the validity of our results, Figure 2 plots the average fraction of correct decisions and average profit per originated loan as a function of the number of completed experimental sessions. These demonstrate no learning effect, a result confirmed by regression results in Table OA.II in the supplementary appendix.

\section{$5.2 \quad$ Incentivizing Screening Effort}

We first analyze the effect of incentives on screening effort. Intuitively, performance incentives can affect the quality of lending decisions if they induce a loan officer to choose higher screening effort, translating into either the collection of borrower information that was not previously available or a more thorough evaluation of available information. The design of our experiment provides us with a straightforward measure of screening effort, namely, the thoroughness with which the loan officer reviews the loan file. Specifically, we record how many of the ten sections of the credit file the loan officer chooses to review before making a decision. In a separate set of sub-treatments meant to make the effort trade-off even 
more stark to loan officers, we charge loan officers Rs 3 for each section of the loan dossier beyond what would be available on the application form ${ }^{19}$. As human subject considerations precluded an experimental design in which loan officers paid us to participate, in these treatments we provide each loan officer with an initial information endowment of Rs 108 (approximately US\$2.25 per experimental session). Participants could choose not to pay to view additional tabs, in which case Rs 108 would be paid to them at the end of the session, in addition to whatever show-up and incentive payments they earn. This information cost was not trivial: purchasing access to all six tabs would cost close to the maximum payout of 20 under the low-powered and origination incentive schemes. We use the amount spent to view loan sections as a second measure of screening effort, capturing the notion of costly information. Because screening effort is not observable to the bank, we do not tie bonus payments to measures of observed effort.

Table V reports the effect of performance pay on screening effort, measured by the number of loan file sections reviewed when the only cost of effort was the loan officer's time (Columns (1) and (2)), as well as when the loan officer was required to pay to view additional tabs (Columns (3) and (4)). High-powered incentives significantly increase screening effort. On average, loan officers facing high-powered incentives viewed .4 additional tabs of information when there was no charge to view tabs (the mean number of tabs viewed was 5.06 when information was free, and 3.99 when information was costly). When information was costly, high-powered incentives had an even stronger effect, increasing the average number of tabs viewed by .8-1.2. These effects are statistically significant across all specifications. Interestingly, we do not observe effort to be significantly lower when loan officers face origination bonuses, although the standard errors are not small enough to rule out meaningful effects. These results confirm that loan officers respond strongly to monetary incentives, and suggest

\footnotetext{
${ }^{19}$ Available for free were basic applicant details and documentation provided by the borrower. Loan officers paid for income statement and balance sheet information, residential and business site visit reports, and trade and credit reference checks.
} 
that performance pay can incentivize effort in the review of borrower information.

\subsection{Risk-Assessment and Risk-Taking}

How do performance incentives affect the perception of credit risk and actual risk-taking? Risk-assessment is easy to measure, as each loan officer is required to enter an internal rating for each loan they evaluate. Before participants made a decision to approve or decline a loan,

they were asked to assess the merit of the application along 15 credit-scoring criteria adapted from the standard internal credit scoring format of an Indian bank. Internal ratings range from 0 to 100 and a higher score indicates higher credit quality, i.e. lower default risk. Internal ratings were not binding for the loan officer's decision. That is, an applicant did not have to attain a minimum score to be considered for a loan. This approach is common practice for consumer and small-enterprise loans for which the bank records internal ratings but does not use predictive credit scoring in the approval process.

In Table VI we first present evidence on the effect of incentives on the perception of credit risk. We find strong evidence that the structure of performance incentives distorts the subjective assessment of credit risk. Loan officers facing incentives that reward loan origination inflate internal ratings by as much as .16 standard deviations. In the specification with loan officer and loan fixed effects (Table VI, Column (2)), we see that the size of the coefficient increases in direct proportion to the incentive that is placed on origination. This is particularly striking for the treatments that paid Rs 50 or Rs 100 (US\$2.25) only if a loan was made and performed, and zero otherwise. Facing this incentive scheme, loan officers inflate internal ratings by up to .3 standard deviations (significant at the 5 percent or better level across all specifications). Taken together, these findings provide strong evidence in support of a behavioral view of performance pay in lending as suggested, for example, by Barberis (2012): incentives that reward origination do not merely affect the propensity to 
take on risk, but in fact distort loan officer judgment and the perception of credit risk.

We next turn to the effect of performance pay on risk-taking. Because the realized outcome of a loan may be a poor proxy of the ex-ante riskiness at the time a loan is originated, we construct a measure of ex-ante risk, by averaging the internal ratings of all loan officers who observed a given file under the baseline incentive. We call this the "loan's average rating." We also calculate the coefficient of variation for the baseline internal score, which is a measure of the degree of disagreement of loan officers about the riskiness of the loan. If high-powered incentives encourage more discerning lending decisions, they will lead loan officers to approve loans with higher average rating and a lower variance. (Indeed, in our data set, the coefficient of variation is strongly correlated with default.)

Table VII tests this hypothesis. Rather than using the loan outcome, which is a noisy measure and depends on idiosyncratic risk, we take advantage of the fact that we had over 100 loan officers rate each loan. We therefore define two measures of the riskiness of a loan, based on the ratings given by the loan officers who evaluated loans under the baseline, lowpowered incentive scheme. The first measure is simply the mean risk rating. The second is the coefficient of variation of the risk rating, which measures the degree of ex-ante disagreement about the quality of a loan.

In the regressions in Table VII, we restrict the sample to loans which a loan officer approved; thus the coefficients give the average risk rating of loans approved under a particular incentive scheme. We find that high-powered incentives lead to more conservative lending, though this result is significant only for the measure of business and financial risk (Columns (5) and (6)). We also find that high-powered incentives cause loan officers to shy away from loans that are risky in the sense that there is greater ex-ante disagreement about the interpretation of information contained in the loan file, as reflected in greater variance of a loan's baseline risk rating. Loans approved under high-powered incentives are characterized by a significantly lower coefficient of variation of their baseline rating. 


\subsection{Lending Decisions and Loan-Level Profit}

In Table VIII, we turn to the impact of performance pay on lending decisions and loan level profit. Loan officers facing origination and repayment bonuses, which do not penalize defaulting loans, are dramatically more likely to approve loan applications, on average (Columns (1) and (2)). The shift from the baseline condition to high-powered incentives leads to only slightly more conservative lending decisions, with the share of loans approved dropping 3.6 and $.04 \%$, significant at the $10 \%$ level for the specification without loan or loan officer fixed effects. This is a small effect relative to the mean acceptance rate of $71 \%$ under the baseline. Incentive schemes that reward origination, on the other hand, result in a dramatic increase in the probability of approval. Under the origination bonus treatment, loan approvals increase by approximately 8 percentage points, statistically significant at the $1 \%$ level. The probability of approval increases monotonically for the two repayment bonus incentives, with the probability of approval increasing by $9-13.5$ and 12.2-15.4 percentage points, respectively.

Of course, incentivizing more or less lending is relatively easy; the more interesting question is whether incentives can make loan officers more discerning. Table VIII, Columns (3) and (4) show that laxer incentives increase the fraction of good loan clients who are approved, roughly in proportion to the overall effect on lending. We find a dramatically different pattern for non-performing loans: loan officers facing the high-powered incentive scheme are 11 percentage points less likely to approve these bad loans, a result that is significant at the five percent level in column (5), despite the smaller sample size. In contrast, we find large increases in the fraction of non-performing loans approved under an incentive scheme that does not penalize poor screening decisions. The pattern is similar for the sample of loans that were initially rejected by the bank, though the statistical significance of the high-powered incentive effect is lost. 
In Table VIII, Columns (9) to (12), we study the effect of performance pay on the profitability of bank lending. Our first measure is the net present value to the lender of repayments, less the amount disbursed, restricting the sample to loans approved by our experimental subjects. ${ }^{20}$ This measure is relevant for a lending institution that seeks to maximize average profitability per loan made, such as a capital-constrained lender. Columns (9) and (10) show that high-powered incentives dramatically improve the profitability of lending, raising profit per loan by US\$ 149 to US\$176 per loan, approximately 5\% of the median loan size. In the final two columns, we consider profit per screened loan, setting the NPV of a loan that is rejected by an experimental subject to zero. This measure makes most sense for a lender whose lending opportunities may be limited, perhaps because they face difficulty sourcing additional clients. Again, we find that high-powered incentives improve profitability by roughly similar magnitudes, though the result is only statistically significant in the specification with loan officer fixed-effects.

In our setting, the net interest margin is quite high (around 30\%), so one might be concerned that high-powered incentives lead loan officers to behave too conservatively, declining profitable loans. In fact, we observe that high-powered incentives improve the quality of origination, and are therefore likely a profitable proposition from the bank's perspective, even when screening costs, reduced volume, and the cost of the incentive payments themselves, are taken into consideration.

\subsection{Deferred Compensation}

Efforts to regulate the compensation of loan originators have often focused on the alleged "short-termism" present in many performance contracts in banking and have therefore aimed at extending the time-horizon of the incentive payments. If loan officers have higher discount

\footnotetext{
${ }^{20}$ Because we do not observe the outcome of loans files that were originally rejected by the lender, we do not include these loans in our profit calculations.
} 
rates than shareholders, however, deferred compensation will blunt the effect of incentives. ${ }^{21}$

In this subsection, we test how the effects of incentive payments vary when the time horizon of payouts is changed. It is worth noting that any compensation that varies with loan repayment must be paid with some delay, as it takes time to observe whether loans perform or not. The intent of our experimental treatments is to vary the extent of this delay in performance based compensation. We are primarily interested in understanding whether deferred compensation weakens incentives for costly screening effort. We therefore restrict attention to the subset of "costly information" treatments, in which loan officers pay to access additional sections of the loan application. We operationalize the concept of deferred compensation by comparing loan officer behavior under immediate performance pay (for low-powered, high-powered and origination incentives) to behavior under a series of treatments, in which incentive payments were awarded after a period of 90 days. $^{22}$

Table IX presents the results of the deferred compensation intervention. In Panel A, we report the effect of deferred compensation on screening effort. Panel B reports on the effect of deferred compensation on risk-taking, and treatment effects of deferred compensation on loan-level profits are reported in Panel C. Note that in contrast to the previous tables, the omitted category and relevant basis for comparison here is the low-powered treatment with costly information. At the foot of the table, we report t-tests comparing the effect of immediate versus deferred compensation. Consistent with the predictions of our model, the results show that deferred compensation significantly weakens the impact of high-powered incentives. This is most apparent in the effect of deferred incentives on screening effort, as measured by loan sections purchased (Table IX, Columns (3) and (4)). In Column (3), the difference between immediate high-powered incentive payments and the exact same payments deferred 90 days is large, [1.225 - (-.454)], and significant at the 1 percent level. While

\footnotetext{
${ }^{21}$ One need not assume loan officers are impatient: credit-constraints or concern about separation from employers could also cause loan officers to discount future payments at high rates.

${ }^{22}$ Loan officers were given the option of collecting cash payments or receiving a check by mail.
} 
high-powered incentives drive loan officers to lend more conservatively (Columns (5) and (6)), deferring those same payments attenuates this effect. High-powered incentives lead loan officers to shy away from loans that appear riskier ex-ante, irrespective of whether the high-powered incentives are deferred (Columns (7) and (8)). Finally, the point estimates of profitability are lower for deferred weak (baseline) incentives, as well as the high-powered incentives, though the difference is significant (at the $10 \%$ level) only for weak incentives.

\subsection{Relaxing Limited Liability}

Just as banks benefiting from deposit insurance and other implicit guarantees may be tempted to take high-risk, low-NPV gambles, so too might front-line loan officers seeking to maximize their variable compensation. To test how the presence of limited liability, an inherent characteristic of virtually all incentive contracts for loan originators, affects loan officer behavior, we randomly assigned loan officers to a treatment in which participants received an initial endowment of Rs 200 (US\$ 4.5) at the beginning of each session, which was theirs to take home unless their incentive payments for the session were negative, in which case the amount of penalties would be deducted from the endowment. The worst outcome possible for a loan officer would be to approve two bad loans and decline four good loans under the high-powered incentive, in which case incentive payments would be Rs -200 . The endowment therefore completely relaxed the limited liability constraint for the session.

Table $\mathrm{X}$ presents the results. We find evidence to suggest that relaxing limited liability indeed increases loan officers' screening effort (Columns (3) and (4)), though the differences are not statistically significant. Surprisingly, loan officers approve loans that appear to be on average lower quality (Column 5) when limited liability is relaxed. When taking lending decisions, loan officers are more conservative without limited liability, though the size of this difference is modest (the difference in coefficients in Column (7) is 2.9 percentage points) and 
not statistically significant. Interestingly, we are unable to detect any systematic difference in the profitability of lending to banks under either scheme. Taken together, these results suggest that ensuring loan officers have more skin in the game has at most modest effects on effort and lending decisions.

\subsection{Do Loan Officer Characteristics Matter?}

The analysis thus far shows that the structure of performance incentives has important effects on loan officer behavior. However, individual ability, experience, and other characteristics may play an important role in determining how loan officers make lending decisions, as well as how they respond to incentives. In any real-world setting, without random assignment, it would be difficult to tease apart the relationship between individual characteristics and performance: for example, higher-ranking individuals may have more advisory support, or be assigned to make decisions on loans that are more risky or informationally opaque. A virtue of our experiment is that we observe loan officers with a variety of demographic and personal characteristics perform an identical task under identical, exogenously assigned conditions.

Previous literature has used various measures to identify determinants of success, often in entrepreneurial activities. Among the traits and dispositions that repeatedly appear as good predictors are biological determinants, such as IQ, gender, and age (see, for example, Djankov et al. (2007), Landier and Thesmar (2009)). Related literature documents cultural predictors, such as occupation of the parent and ethnic ties. The psychology literature has also identified broad personality factors associated with entrepreneurial start-up and success, such as risk taking, neuroticism and the need to be motivated to achieve (de Mel, McKenzie and Woodruff (2009), Zhao and Seibert (2006)). Although there is much reason to believe

that, similar to many other tasks that require a tradeoff between risk and return, patterns of loan officer decision making are likely to be influenced by personal characteristics, we are not 
aware of any prior evidence on what personality characteristics predict success in lending. ${ }^{23}$ In this section, we explore these open empirical question by considering, first, the effect of personal attributes on loan officer decision making and, second, heterogeneity in the response to performance incentives among loan officers with different demographic characteristics.

\subsubsection{Loan Officer Characteristics and Lending Decisions}

Before we explore heterogeneity in the response to incentives, Table XI examines how lending decisions vary with loan officer characteristics. To do this, we augment equation 1 with a demographic characteristic, such as age or gender, or the measurement of a personality trait. We omit other loan officer characteristics from the regression, but continue to include treatment dummies, as well as week and randomization stratum fixed effects.

The results are intriguing and demonstrate that demographic characteristic and personality traits significantly affect loan officer behavior. A loan officer's age has a small, but perceptible effect on internal ratings and loan approvals: a loan officer ten years older rates a file, on average, .06 standard deviations higher quality, and is one percentage point more likely to approve a given loan application. The largest effects appear in loan officer effort. Loan officers with the highest rank (5/5) spend, on average, Rs 12 more per session (from a mean of 24) on reviewing costly information than loan officers at the lowest rank $(1 / 5)$.

A large literature examines the performance of private versus government-owned banks (see, for example, LaPorta, Lopez-De-Silanes and Shleifer (2002) and Cole (2009)). An unanswered question in that literature is whether incentives alone can explain differences in performance, or whether the type of person working in a public sector undertaking may behave differently. Table XI shows that employees of private sector banks work harder (are willing to pay a higher cost to observe information), and rate the same loans higher. Importantly, they also seem to make better decisions: they are more likely to accept good

\footnotetext{
${ }^{23}$ For a comprehensive review of the related psychology literature, see Frese and Rauch (2007).
} 
loans, no more likely to accept bad loans, and their decisions are on average $\$ 75$ (or $2.2 \%$ percent of the median loan size) more profitable than the decisions of public sector bankers.

We next examine whether lending behavior can be predicted by standard measures of personality traits. Following the experiment, we asked 53 loan officers to complete a standard personality test (John, Donahue and Kentle (1991)). ${ }^{24}$ While these measures have been validated and are widely used in experimental economics, to the best of our knowledge this is the first application in finance. We find that personality matters: agreeable and conscientious individuals spend significantly more on costly information, while neurotic individuals shirk. Personality also affects ratings, and the ability to correctly identify good loans. These effects are economically meaningful: a loan officer at the 75th percentile of the agreeability distribution will approve 4.3 percentage points more good loans than an individual at the 25th percentile of the agreeableness distribution. Two of the five personality measures predict profitability: extroverts make better decisions, while more neurotic individuals turn down so many good loans that their average profitability is lower.

Finally, we analyze the effect of risk aversion and patience (more patient individuals have lower discount rates) on behavior. We find that, on average, risk averse individuals spend less on costly information, but are more likely to approve both good and bad loans, though the latter effects are small (the inter quartile range for risk aversion on accepting good applications is 1.2 percentage points).

In summary, loan officer identity seems to matter. Different individuals, facing the identical information set and identical incentives, behave quite differently, with important consequences for lending. In the final section, we turn to the possibility that the incentive schemes themselves have heterogeneous effects.

\footnotetext{
${ }^{24}$ Summary statistics of these characteristics are given in Table II, Panel B.
} 


\subsubsection{Loan Officer Characteristics and the Response to Incentives}

Does the response of credit officers to incentives vary with individual characteristics, such as age or experience? Table XII reports regressions which augment equation (1) with a loan officer characteristic, and interact that characteristic with treatment dummies. Because there are many more interactions possible than the scope of this paper allows us to report, we focus on what we believe are the most salient characteristics. ${ }^{25}$

Panel A examines whether the effect of incentives varies with the age of the loan officer. ${ }^{26}$ The odd columns present the main effect of age and the incentive schemes, while the even columns report the interaction between age and incentives. We find that older officers rate loans higher, but that their ratings are less responsive to incentives: particularly, when faced with an origination bonus, a 50 year old loan officer increases average ratings $40 \%$ less than a 30 year-old loan officer.

Turning to rank, we find that the lowest ranking loan officers barely reduce expenditures on information when faced with an origination bonus scheme, but higher ranked loan officers decrease their expenditures substantially. Perhaps the most significant difference in response to incentives occur by gender. Men rate loans higher, but women inflate ratings significantly more when facing origination bonuses. Men also accept a significantly higher fraction of loans under low-powered incentives (.06). While women make more lenient lending decisions under high-powered incentives, men become stricter. Finally, women respond to the origination bonus by increasing their acceptance rates dramatically more than men. While the previous section showed private sector bankers behave dramatically differently, Panel D suggests that they respond in generally similar ways to incentives. One exception is in Column (2): private bankers act more like homo oeconomicus, reducing expenditure of information much more than public sector bankers when faced with origination bonuses. Finally, we note that, at

\footnotetext{
${ }^{25}$ Additional interaction results are reported in the working paper version.

${ }^{26}$ We divide age by 10 to avoid very small coefficients.
} 
least if evaluated by their willingness to pay a cost to obtain more information, agreeable loan officers make better employees. They also shirk approximately one-fourth less when facing the origination incentive.

Risk aversion and time preferences (not reported) do not have dramatic impact on the efficacy of incentive schemes (results available in working paper). The effect of incentives appears generally to be weaker on individuals with lower discount rates. However, we do not find that risk-averse individuals become particularly conservative in lending decisions when faced with the high-powered incentive scheme.

In short, we find some evidence of the heterogeneous effect of incentives, though we are not persuaded that the weight of the evidence is strong enough to recommend that banks provide different incentive schemes for different types of people. In contrast, the first-order effects of individual characteristics on lending behavior are quite meaningful. Incentive contracts may be important in helping banks attract workers whose personal characteristics are compatible with profitable lending.

\section{Discussion and Conclusion}

Recent research has presented convincing evidence that incentives rewarding loan origination may cause severe agency problems and increase credit risk, either by inducing lax screening standards Agarwal and Ben-David (2012), or by tempting loan officers to game approval cutoffs even when such cutoffs are based on hard information (Berg, Puri and Rocholl, 2012). Yet, to date there has been no evidence on whether performance-based compensation can remedy these problems. The literature is similarly silent on the degree to which contracting constraints inherent to the structure of performance incentives in lending, such as deferred compensation and limited liability, affect how loan officers respond to pay-for-performance.

In this paper, we analyze the underwriting process of small-business loans in an emerging 
market, using a series of experiments with experienced loan officers from Indian commercial banks. The loan files evaluated in these experiments consist of the loan applications of entrepreneurs seeking their first commercial loan, which requires extensive screening effort and is therefore particularly sensitive to loan officer judgment.

We provide the first rigorous test of theories of loan officer decision-making, using evidence from a series of randomized experiments. Because our experimental design allows us to capture normally unobservable aspects of loan officer behavior, such as effort spent in the evaluation of borrower information, we directly measure the relationship between incentives, effort, and performance. We additionally observe loan officers' subjective risk-assessment, which allows us to trace the impact of incentives on the perception of credit risk.

Comparing three commonly implemented classes of incentive schemes, we find a strong and economically significant impact of monetary incentives on screening effort, risk-assessment, and the profitability of originated loans. High-powered incentives that penalize the origination of non-performing loans while rewarding profitable lending decisions cause loan officers to exert greater screening effort, approve fewer loans and increase the profits per originated loan. In line with the predictions of a simple model of incentives and loan officer decisionmaking, these effects are attenuated when deferred compensation is introduced. Interestingly, we find that incentives affect not only actual risk-taking, but also loan officers' subjective perception of credit risk: more permissive incentive schemes lead loan officers to rate loans as significantly less risky than the same loans evaluated under pay-for-performance.

While we acknowledge that there are limitations to our set up as compared to a pure field experiment, the data in this study represent the allocation of approximately US\$ 88 million in credit, something that would be difficult to achieve in a field experiment. The combination of a lab and field experiment enables us to ask loan officers with very different backgrounds and skills to evaluate exactly the same loans under exogenously assigned incentives and allows us to measure aspects of loan officer behavior that would otherwise be unobservable, such 
as screening effort in the evaluation of borrower information and the subjective assessment of credit risk. The experiments in this paper thus represent the first step of an ambitious agenda to fully understand the loan underwriting process.

Lenders have increasingly relied on credit scoring models rather than human judgment. But it is unclear whether credit scoring models can outperform human judgment, particularly in informationally opaque credit markets, such as the one we study. Nor is it obvious what individual characteristics are associated with screening ability and to what extent they help or hinder the use of performance incentives as a tool to manage credit-risk in commercial lending. The results in this paper provide a first step in answering these important questions. 


\section{Appendix}

\section{A Simple Model of Loan Officer Decision Making}

To guide the analysis, we describe a simple model that highlights the key frictions that may prevent the implementation of the optimal contract, and describes how changes in loan officer incentives affect screening behavior and lending decisions.

Agents. The model encompasses firms, loan officers, and the bank. The bank is riskneutral, while loan officers are risk-averse with $\mathrm{u}_{\mathrm{w}}>0$ and $\mathrm{u}_{\mathrm{ww}}<0$. Firms seek to borrow 1 unit of capital from the bank. They invest in a project which either succeeds, generating income, or fails, leaving zero residual value. There are two types of firms: good firms of type $\theta_{G}$ with probability of investment success $\mathrm{p}$, and bad firms of type $\theta_{B}$, with probability of investment success 0 . The ex-ante fraction of good firms is $\pi$. We assume that the bank has a net cost of capital normalized to 0 , and charges interest rate $r>0$. If the bank makes a loan that is repaid, it therefore earns net interest margin $r$. If the loan defaults, the bank loses 1 unit of capital. If the bank were to lend 1 unit of capital to all applicants, a loan would be repaid with probability $\pi \mathrm{p}$ and earning expected return $\pi \mathrm{p}(1+r)-1$. We assume this amount to be negative, so that it is not profitable for the bank to lend to all applicants.

Information and Screening. While a firm's type is not observed, a loan officer may screen a loan application in an attempt to determine the firm's type. This requires effort, which comes at private cost $e>0$ to the loan officer. We additionally allow for the possibility that an intrinsically motivated loan officer derives non-pecuniary utility $m \geq 0$ from screening, and assume that both $e$ and $m$ are specific to an individual loan officer and independent of monetary incentives. If a loan officer engages in screening, she observes either a fully informative bad news signal, $\sigma_{B}$, indicating that the firm is type $\theta_{B}$, and will default with

certainty , or the "no bad news" signal $\sigma_{G}$. Bad firms generate a bad signal with probability 
$\gamma$, and a good signal with probability $1-\gamma$. Good firms generate a good signal with certainty. Hence, the probability of observing a bad signal conditional on firm type is

$$
P\left(\sigma_{B}\right)=\left\{\begin{array}{lll}
\gamma & \text { if borrower is type } & \theta_{B} \\
0 & \text { if borrower is type } & \theta_{G}
\end{array}\right.
$$

It follows that the posterior probability of a firm being bad after receiving a bad signal is $\mathrm{P}\left(\theta_{\mathrm{B}} \mid \sigma_{\mathrm{B}}\right)=1$, and the probability of the firm being good after observing a good signal is $\mathrm{P}\left(\theta_{\mathrm{G}} \mid \sigma_{\mathrm{G}}\right)=\frac{\pi}{\pi+(1-\gamma)(1-\pi)}$. We assume that it is profitable to lend to a firm with a good signal, even when screening costs are taken into consideration, so that

$$
\pi\{p r+(1-\mathrm{p})(-1)\}+(1-\pi)\{\gamma \cdot 0+(1-\gamma)(-1)\} \geq e-m
$$

Contracts. The bank may offer the loan officer a contract $\mathbf{w}=\left[w, w_{D}, \bar{w}\right]$ to induce screening effort. The contract specifies a payment $\bar{w}$ for declining a loan application, and contingent payments for approving a loan that subsequently performs $w_{P}$ and for approving a loan that subsequently defaults, $w_{D}$, where $w_{P}, \bar{w} \in[0, r]$ and $w_{D} \in[-1,0]$. The bank's problem is to choose $\mathbf{w}=\left[w_{P}, w_{D}, \bar{w}\right]$ to maximize profitability. The bank does not observe the outcome of a loan that is screened out by the loan officer.

Expected Utility. Loan officers choose the return to three possible actions: declining a loan without screening, approving the loan without screening, or screening the loan application and approving the loan only if no bad signal is observed. We consider the outcome of each action in turn. If a loan officer rejects a loan without screening, her expected utility is simply $u_{R}=u(\bar{w})$. If the loan officer approves a loan without screening, her expected utility is

$$
u_{N S}=\pi \mathrm{p} u\left(w_{P}\right)+(1-\pi \mathrm{p}) u\left(w_{D}\right)
$$


If an officer screens and approves only when no negative signal is observed, her utility is ${ }^{27}$

$$
u_{S}=\pi \mathrm{p} u\left(w_{P}\right)+\{1-\pi \mathrm{p}-\gamma(1-\pi)\} u\left(w_{D}\right)+\{(1-\pi) \gamma\} u(\bar{w})-e+m
$$

Incentive Compatibility. We begin by remarking that, in the case of a risk-neutral loan officer with unlimited wealth, the efficient outcome can be obtained by setting $\mathbf{w}=[r,-1,0]$, effectively selling the loan to the loan officer and making her the residual claimant. However, in practice this contract is expensive for the bank (as it gives the entire profit from the loan to the loan officer) and not feasible in practice, as the loan officer would be liable for the total amount of the loan in case of default. Hence, if the bank is to motivate the loan officer to exert screening effort, it needs to offer a contract that satisfies two incentive constraints: $u_{S} \geq u_{N S}$ and $u_{S} \geq u_{R}$. The first constraint requires that the returns to effort be greater than the cost of effort. This condition simplifies to:

$$
\gamma\left\{u(\bar{w})-u\left(w_{D}\right)\right\}(1-\pi)+m \geq \tilde{e}
$$

The second constraint requires that the loan officer prefer screening to declining all loans:

$$
\pi p u\left(w_{P}\right)+\{1-\pi p+\gamma(\pi-1)\} u\left(w_{D}\right)-\{1+\gamma(\pi-1)\} u(\bar{w})+m \geq \hat{e}
$$

In practice, since both constraints are upper bounds for the cost of effort, only one will bind. Nevertheless, the fact that $w_{D}$ and $\bar{w}$ slacken one constraint while tightening the other suggests it may be difficult to obtain the optimal incentive scheme, and indeed the parameter space admits ranges such that profitable lending is not possible. No matter which constraint binds, it is always weakly easier to induce effort when the cost of effort is lower,

\footnotetext{
${ }^{27}$ From these conditions, we can also derive the profit of the bank in each case. If a loan officer rejects a loan without screening, the bank's profit is $\Pi_{R}=-\bar{w}$. If the loan officer approves a loan without screening, the bank's profit is $\Pi_{N S}=\pi \mathrm{p}\left(r-w_{P}\right)-(1-\pi \mathrm{p})\left(1+w_{D}\right)$, and if the loan officer screens and approves a loan only if no bad signal is observed, expected profit is $\Pi_{S}=\pi p\left(r-w_{P}\right)-[\pi(1-p)+(1-\pi)(1-\gamma)]\left(1+w_{D}\right)-[(1-\pi) \gamma] \bar{w}$.
} 
the penalty for making a non-performing loan increases, and the outside option of declining a loan decreases. The effect of increasing $w_{P}$ depends on which incentive compatibility constraint binds. Loan officers can always be induced to lend, although not necessarily in a manner that is profitable for the bank.

In the experiment, we focus on the following testable predictions that characterize incentive schemes commonly employed in commercial lending. Taken literally, the model predicts that loan officers will either screen all loans, or not screen any loans. However, a simple extension in which $e$ varies by loan, in a way that is observable only to the loan officer, would generate non-corner solution in screening effort, and the following comparative statics with respect to the average effort level exerted by a loan officer.

Proposition 1 (Incentive power) $\frac{\partial \tilde{\mathrm{e}}}{\partial w_{D}}$ and $\frac{\partial \hat{e}}{\partial w_{D}}<0$ and $\frac{\partial \tilde{e}}{\partial w_{P}}>0$. An origination piece rate, as often employed in commercial lending, leads to low screening effort, indiscriminate lending and high default rates. By contrast, high-powered incentives that reward the origination of performing loans while penalizing the approval of bad loans lead to greater effort, more conservative lending and lower defaults.

Proposition 2 (Deferred compensation) Let $\delta \in(0,1)$ denote the time discount rate of loan officer $i$. Then $\delta u<u \forall \delta$. Deferred compensation weakens the incentive power of any performance based contract for a loan officer with a positive discount rate, as the cost of effort is not discounted while monetary rewards are.

Proposition 3 (Limited liability) Because $\frac{\partial \tilde{e}}{\partial w_{D}}$ and $\frac{\partial \hat{e}}{\partial w_{D}}<0$, increasing a loan officer's liability for non-performing loans from $w_{D} \geq 0$ to $w_{D} \in(-r, 0)$ leads to greater screening effort. More generally, relaxing the limited liability constraint increases the incentive power of any performance based contract.

Proposition 4 (Intrinsic motivation). $\frac{\partial \tilde{e}}{\partial m}$ and $\frac{\partial \hat{e}}{\partial m}>0$. The smaller the utility cost of scrutinizing and the stronger the loan officer's intrinsic motivation the greater will be the officer's observed screening effort, irrespective of the incentive power of the contract. 


\section{References}

Agarwal, Sumit and Faye H. Wang, "Perverse Incentives at the Banks? Evidence from a Natural Experiment," Federal Reserve Bank of Chicago. Working Paper WP-09-08., 2009.

- and Itzhak Ben-David, "Do Loan Officer Incentives Lead to Lax Lending Standards?," Ohio State University, Fisher College of Business. Working Paper WP-2012-7., 2012.

Akerlof, George A and William T Dickens, "The Economic Consequences of Cognitive Dissonance," American Economic Review, June 1982, 72 (3), 307-19.

Baker, George, Michael Jensen, and Kevin Murphy, "Compensation and Incentives: Practice vs. Theory," Journal of Finance, July 1988, 43 (3), 593-616.

Balachandran, Sudharkar, Bruce Kogut, and Hitesh Harnal, "Did Executive Compensation Encourage Extreme Risk-Taking in Financial Institutions?," Working Paper, Columbia Business School., 2011.

Bandiera, Oriana, Iwan Barankay, and Imran Rasul, "Incentives for Managers and Inequality Among Workers: Evidence From a Firm-Level Experiment," Quarterly Journal of Economics, 2007, 122 (2), 729-773.

_, _, and _, "Social Connections and Incentives in the Workplace: Evidence From Personnel Data," Econometrica, 07 2009, 77 (4), 1047-1094.

_ , _, and _, "Team Incentives: Evidence from a Field Experiment," Working Paper, 2011.

Barberis, Nicholas, Psychology and the Financial Crisis of 2007-2008, Cambridge, MA: MIT Press, 2012. 
Bebchuk, Lucian, Alma Cohen, and Holger Spamann, "The Wages of Failure," Yale Journal on Regulation, 2010, 27, 257-282.

- and Holger Spamann, "Regulating Bankers' Pay," Georgetown Law Journal, 2010, 98 (2), 247-287.

Berg, Tobias, Manju Puri, and Jorg Rocholl, "Loan Officer Incentives and the Limits of Hard Information," Mimeo. Duke University Fuqua School of Business, 2012.

Berger, Allen N and Gregory F Udell, "Relationship Lending and Lines of Credit in Small Firm Finance," Journal of Business, July 1995, 68 (3), 351-81.

Berger, Allen N. and Gregory F. Udell, "Small Business Credit Availability and Relationship Lending: The Importance of Bank Organisational Structure," Economic Journal, February 2002, 112 (477), F32-F53.

_, Leora F. Klapper, and Gregory F. Udell, "The ability of banks to lend to informationally opaque small businesses," Journal of Banking ES Finance, December 2001, 25 (12), 2127-2167.

Bolton, Patrick, Hamid Mehran, and Joel Shapiro, "Executive Compensation and Risk-Taking," Working Paper, Federal Reserve bank of New York., 2010.

Boot, A., "Relationship Banking: What do we know?," Journal of Financial Intermediation, 2000, (9), 7-25.

Cole, Shawn A., "Financial Development, Bank Ownership, and Growth. Or, Does Quantity Imply Quality?," The Review of Economics and Statistics, 2009, 91 (1), 33-51.

de Mel, Suresh, David McKenzie, and Christopher Woodruff, "Innovative Firms or Innovative Owners? Determinants of Innovation in Micro, Small and Medium Enterprises," World Bank Policy Research Paper 4934, 2009. 
Djankov, Simeon, Yingyi Qian, Gerard Roland, and Ekaterina Zhuravskaya, "What Makes a Successful Entrepreneur? Evidence from Brazil," Mimeo, July 2007.

Edmans, Alex and Qi Liu, "Inside Debt," Review of Finance, April 2011, 15 (1), 75-102.

Fahlenbach, Rudiger and Rene Stulz, "Bank CEO Incentives and the Credit Crisis," Forthcoming, Journal of Financial Economics, 2012.

Frese, Michael and Andreas Rauch, "Let's Put the Person Back into Entrepreneurship Research: A Meta-Analysis on the Relationship Between Business Owners' Personality Traits, Business Creation, and Success," European Journal of Work and Organizational Psychology, 2007, 16 (4).

Gibbons, Robert S., "Incentives in Organizations," Journal of Economic Perspectives, 1998, $12(4), 115-132$.

Harhoff, Dietmar and Timm Korting, "Lending relationships in Germany - Empirical evidence from survey data," Journal of Banking $\& 3$ Finance, October 1998, 22 (10-11), $1317-1353$.

Harrison, Glenn W, John A List, and Charles Towe, "Naturally Occurring Preferences and Exogenous Laboratory Experiments: A Case Study of Risk Aversion," Econometrica, 2007, 75 (2), 1468-1482.

Heider, Florian and Roman Inderst, "Loan Prospecting," Forthcoming, Review of Financial Studies., 2011.

Hertzberg, Andrew, Jose Liberti, and Daniel Paravisini, "Information and Incentives Inside the Firm: Evidence from Loan Officer Rotation," The Journal of Finance, 2010.

Jensen, Michael and Kevin Murphy, "Performance Pay and Top-Management Incentives," Journal of Political Economy, April 1990, 98 (2), 225-64. 
John, O. P., E. M. Donahue, and R.L. Kentle, "The Big Five Inventory-Versions 4a and 54," Berkeley, Institute of Personality and Social Research, Berkeley, CA: University of California., 1991.

Keys, Benjamin J., Tanmoy K. Mukherjee, Amit Seru, and Vikrant Vig, "Did Securitization Lead to Lax Screening? Evidence from Subprime Loans," Quarterly Journal of Economics, 2010, 125 (1).

Kremer, Michael, Supreet Kaur, and Sendhil Mullainathan, "Self-Control at Work: Evidence from a Field Experiment," Mimeo. Harvard University., 2010.

Landier, Augustin and David Thesmar, "Financial Contracting with Optimistic Entrepreneurs: Theory and Evidence," Review of Financial Studies, 2009, 22 (1), 117-150.

LaPorta, Rafael, Florencio Lopez-De-Silanes, and Andrei Shleifer, "Government Ownership of Banks," Journal of Finance, 02 2002, 57 (1), 265-301.

Lazear, Edward P., "Performance Pay and Productivity," American Economic Review, December 2000, 90 (5), 1346-1361.

Lazear, Edward P and Sherwin Rosen, "Rank-Order Tournaments as Optimum Labor Contracts," Journal of Political Economy, October 1981, 89 (5), 841-64.

Liberti, Jose and Atif Mian, "The Effect of Hierarchies on Information Use," Review of Financial Studies, 2009, 22 (4), 4057-4090.

Liberti, Jose M., "Initiative, Incentives and Soft Information: How does Delegation Impact the Role of Bank Relationship Managers?," IFA Working Paper No.404, 2005.

Margiotta, Mary M. and Robert A Miller, "Managerial Compensation and the Cost of Moral Hazard," International Economic Review, 2002, 41 (3), 669-719. 
Mayraz, Guy, "Wishful Thinking," Working Paper, Oxford University, Department of Economics, 2012.

Mian, Atif, "Distance Constraints: The Limits of Foreign Lending in Poor Economies," The Journal of Finance, 2006, 61 (3), 1465-1505.

Moore, Don A., Lloyd Tanlu, and Max H. Bazerman, "Conflict of Interest and the Intrusion of Bias," Judgment and Decision Making, 2003, 70 (2), 369-393.

Murphy, Kevin, "Executive Compensation," Working paper, University of Southern California., 1998.

Nalbantian, Haig and Andrew Schotter, "Productivity under Group Incentives: An Experimental Study," American Economic Review, june 1997, 87 (3), 314-341.

Petersen, Mitchell A., "Objective and Subjective Information: Implications for Finance and Financial Research," Mimeo, Northwestern University., 2004.

Petersen, Mitchell A and Raghuram G Rajan, "The Benefits of Lending Relationships: Evidence from Small Business Data," Journal of Finance, March 1994, 49 (1), 3-37.

Petersen, Mitchell A. and Raghuram G. Rajan, "The Benefits of Lending Relationships: Evidence from Small Business Data," The Journal of Finance, 1994, 49 (1), 3-37.

Qian, Jun, Philip E. Strahan, and Zhishu Yang, "The Impact of Incentives and Communication costs on Information Production: Evidence from Bank Lending," Mimeo, 2011, (1).

Rajan, Raghuram, Fault Lines, Princeton, NJ: Princeton University Press, 2010.

Santikian, Lori, "The Ties than Bind: Bank Relationships and Small Business Lending," Mimeo. University of Southern California, Marshall School of Business., 2011. 
Stein, Jeremy C., "Information Production and Capital Allocation: Decentralized versus Hierarchical Firms," The Journal of Finance, 2002, 57 (5), 1891-1921.

Udell, Gregory F., "Loan Quality, Commercial Loan Review and Loan Officer Contracting," Journal of Banking and Finance, 1989, 13 (3), 367-382.

Zhao, H. and S. E Seibert, "The Big Five personality dimensions and entrepreneurial status: A Meta-analytical Review," Journal of Applied Psychology, 2006, 91 (2), 259-271. 


\section{Figures and Tables}

Figure 1: Loan Officer Performance

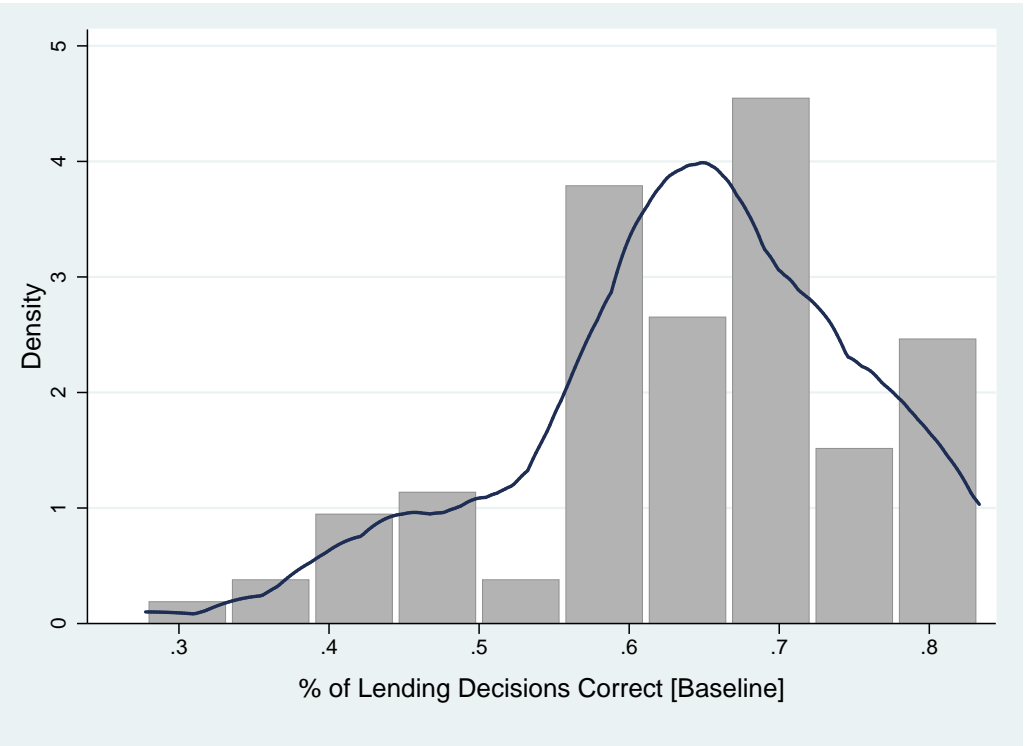

Notes: This figure shows the distribution of loan officer performance, measured by the average percentage of correct decisions per session under the Baseline treatment. The line plots the Kernel density of the performance distribution. We define a correct lending decision as approving an ex-post performing loan or declining an ex-post non-performing loan. 
Figure 2: Learning During the Experiment

(a) Accuracy of Lending Decisions

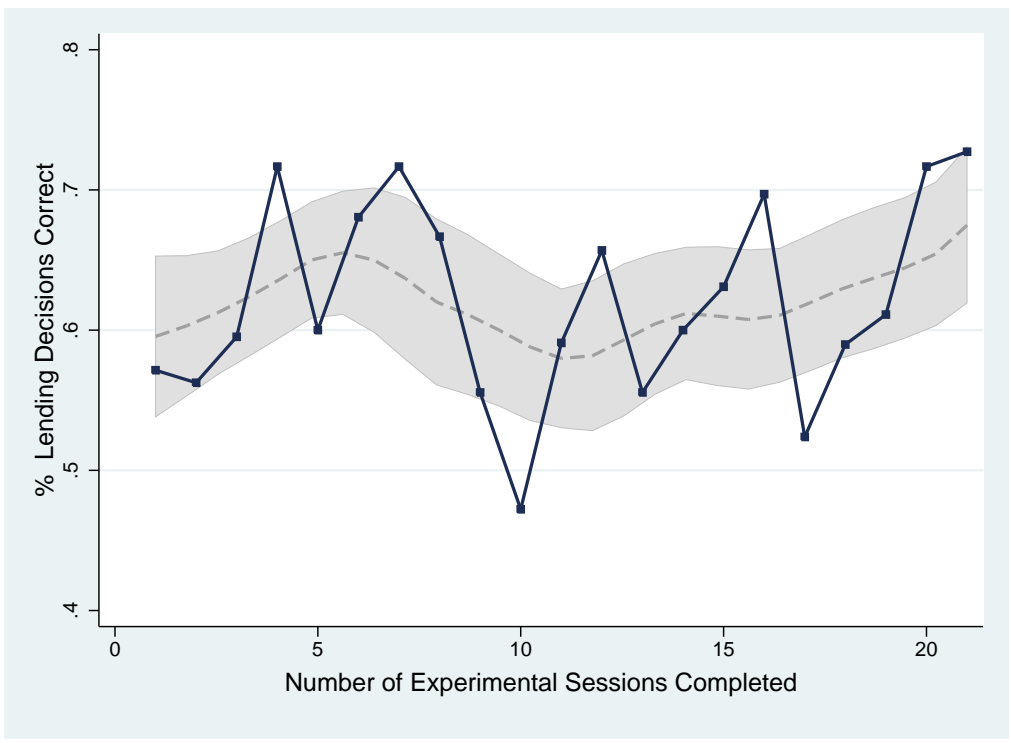

(b) Profitability of Lending Decisions

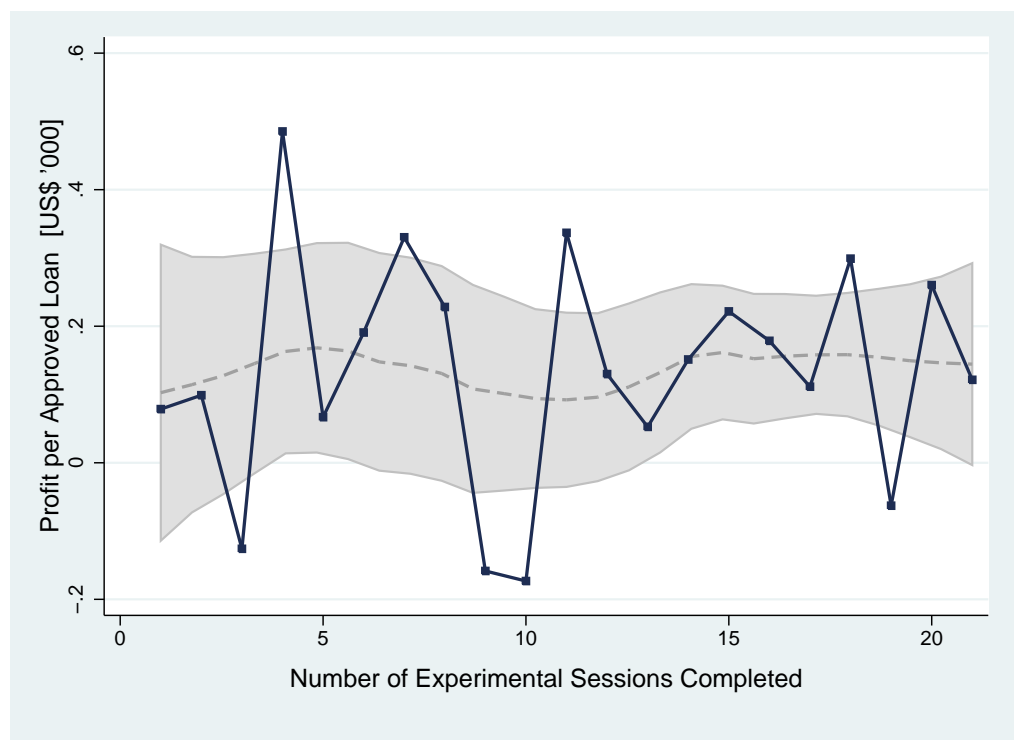

Notes: This figure examines the presence of learning effects over the course of the experiment by plotting (a) the percentage of correct decisions by the total number of experimental sessions completed and (b) the profit per approved loan by the number of experimental sessions completed. A correct lending decision is defined as a loan officer correctly approving a performing loan or correctly declining a loan that became delinquent. The dashed lines and shaded areas are Kernel-weighted local polynomial regressions with corresponding $95 \%$ confidence intervals. 
Figure 3: Distribution of Internal Ratings

(a) Non-performing Loans

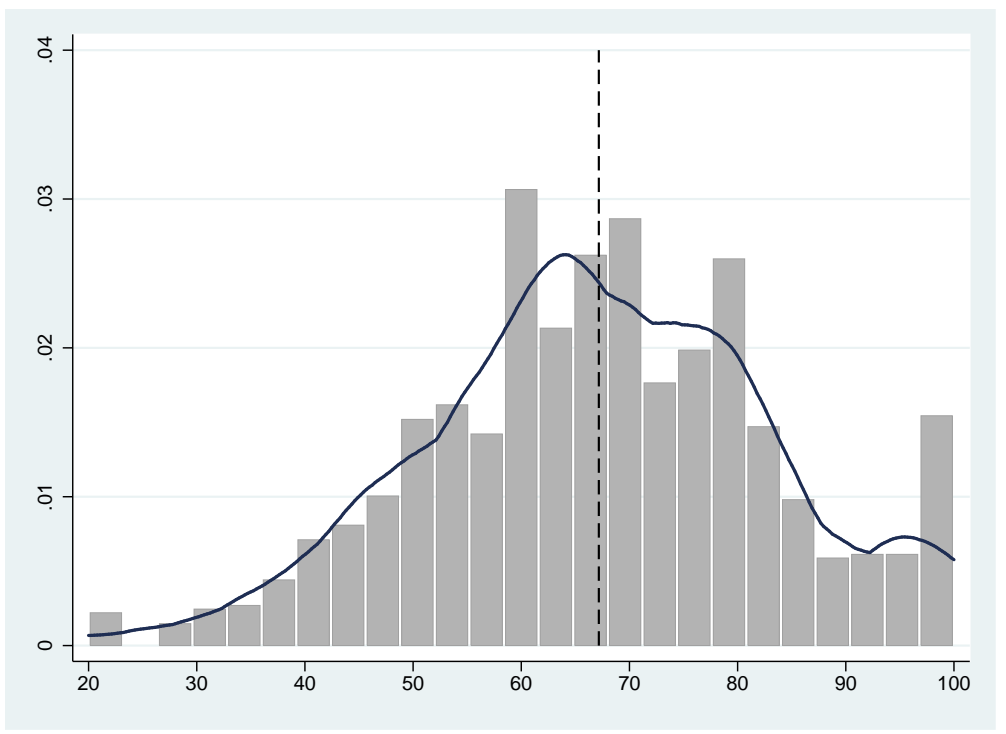

(b) Performing Loans

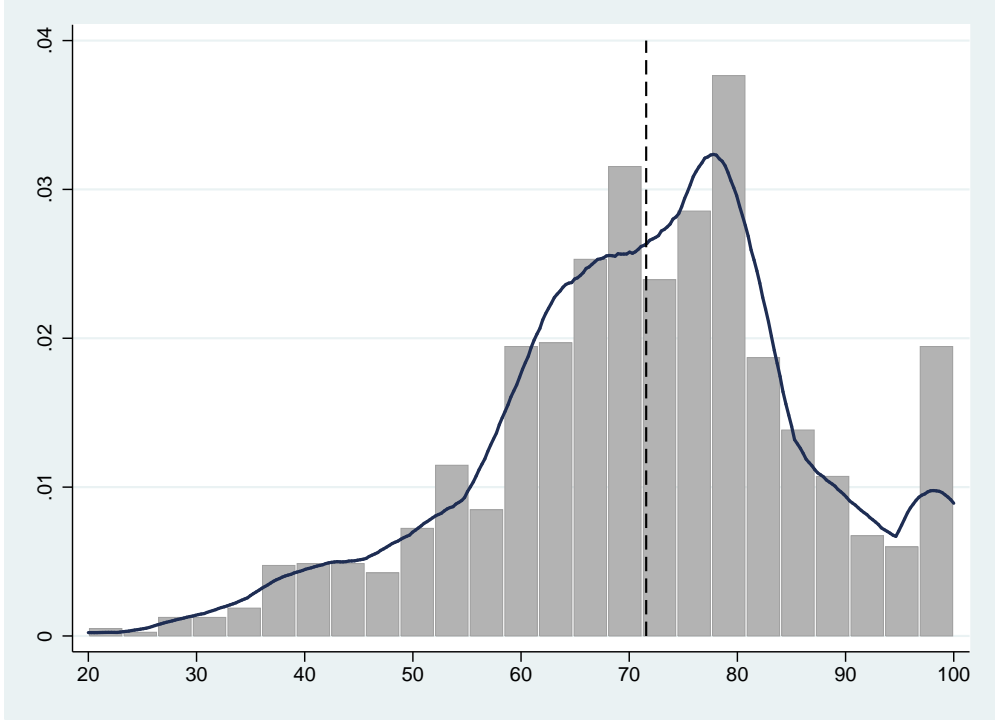

Notes: This figure plots the distribution of internal ratings assigned to loans evaluated under the baseline treatment. Panel (a) shows the distribution of risk-ratings for the sample of non-performing loans and loans that were declined by the Lender ex-ante; panel (b) plots the distribution for performing loans. Vertical lines show the median of the distribution. A Kolgomorov-Smirnov test rejects equality of distributions at 1\% (p-value $<0.001)$. 


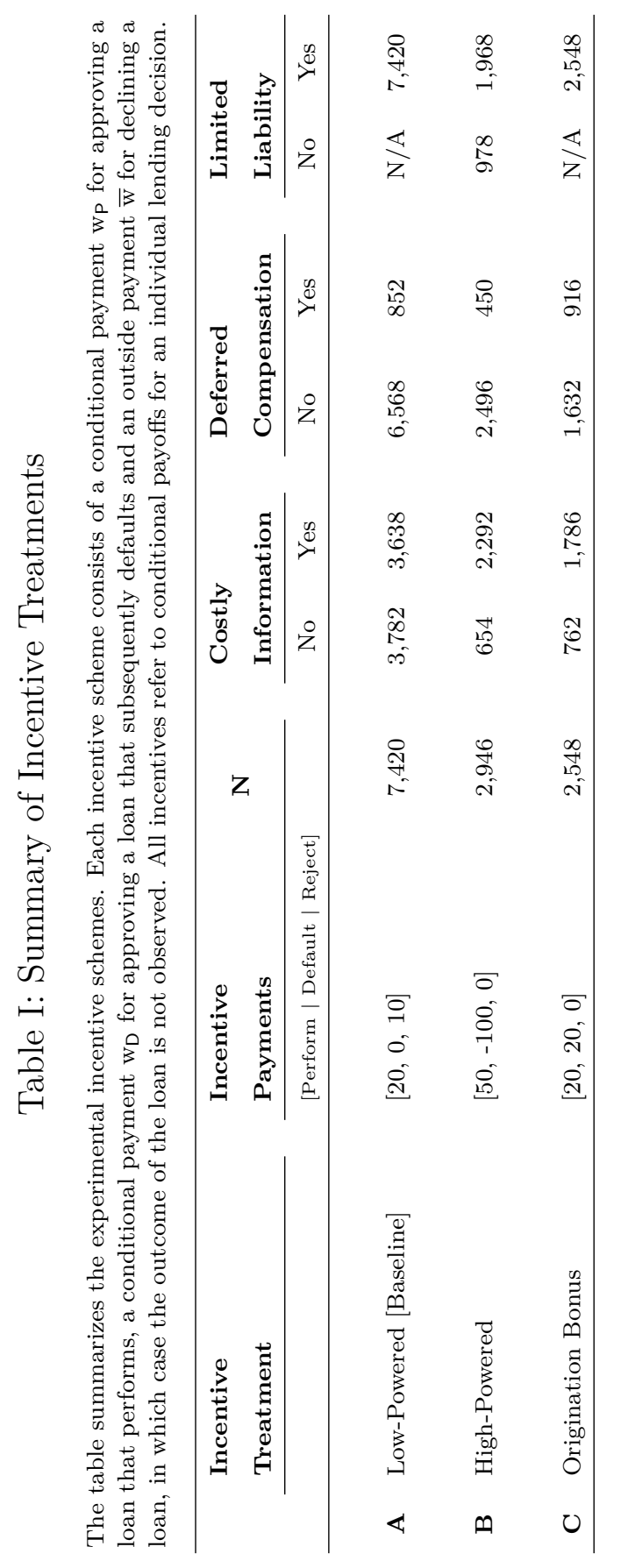




\section{Table II: Loan Officer Summary Statistics}

Panel A reports demographic summary statistics of the participants (Columns (1) to (4)), comparing experiment participants to the staff of all loan officers of a large public sector bank in the state in which the experiment was carried out (Columns (5) to (8)). Rank is the loan officer's seniority level in the bank ranging from 1 (lowest) to 5 (highest). Experience is the total number of years the participant has been employed with the bank. Branch Manager is a dummy variable indicating whether the participant has ever served as a branch manager or in a comparable management role. Business Experience is a dummy variable taking on a value of 1 if a loan officer reports having any previous business experience outside banking. Panel B shows summary statistics for the subsample of loan officers that completed the personality test.

Panel A

\begin{tabular}{|c|c|c|c|c|c|c|c|c|}
\hline & \multicolumn{4}{|c|}{ Experiment participants $[N=209]$} & \multicolumn{4}{|c|}{ Bank sample $[\mathrm{N}=3,111]$} \\
\hline & $\mathrm{N}$ & Mean & Median & StdDev & $\mathrm{N}$ & Mean & Median & StdDev \\
\hline & $(1)$ & $(2)$ & $(3)$ & (4) & $(5)$ & (6) & $(7)$ & $(8)$ \\
\hline Male & 206 & 0.90 & 1.00 & 0.30 & 3,111 & 0.9 & 1.00 & 0.30 \\
\hline Age & 206 & 37.60 & 35.00 & 10.94 & 3,111 & 37.9 & 35.00 & 12.0 \\
\hline Education [Master's degree] & 200 & 0.33 & 0.00 & 0.47 & $\mathrm{~N} / \mathrm{A}$ & $\mathrm{N} / \mathrm{A}$ & $\mathrm{N} / \mathrm{A}$ & $\mathrm{N} / \mathrm{A}$ \\
\hline Experience [Years] & 206 & 12.76 & 10.00 & 11.30 & 3,111 & 13.90 & 11.00 & 13.00 \\
\hline Rank [1 (Lowest) - 5 (Highest)] & 206 & 1.94 & 2.00 & 1.00 & 3,111 & 1.60 & 2.00 & 0.75 \\
\hline Branch Manager Experience & 206 & 0.33 & 0.00 & 0.47 & $\mathrm{~N} / \mathrm{A}$ & $\mathrm{N} / \mathrm{A}$ & $\mathrm{N} / \mathrm{A}$ & $\mathrm{N} / \mathrm{A}$ \\
\hline Business Experience Indicator & 206 & .47 & 0.00 & .50 & $\mathrm{~N} / \mathrm{A}$ & $\mathrm{N} / \mathrm{A}$ & $\mathrm{N} / \mathrm{A}$ & $\mathrm{N} / \mathrm{A}$ \\
\hline Private Sector Banker & 206 & 0.20 & 0.00 & 0.40 & & & & \\
\hline
\end{tabular}

Panel B

\section{Experiment participants}

with personality test $[\mathrm{N}=53]$

\begin{tabular}{lcccc} 
& \multicolumn{4}{c}{ with personality test $[\mathrm{N}=53]$} \\
\cline { 2 - 5 } & $\mathrm{N}$ & Mean & Median & StdDev \\
& $(1)$ & $(2)$ & $(3)$ & $(4)$ \\
\hline BFI Extroversion & 50 & 3.46 & 3.38 & 0.53 \\
BFI Agreeableness & 50 & 3.90 & 3.89 & 0.51 \\
BFI Conscientiousness & 50 & 3.92 & 3.94 & 0.62 \\
BFI Neuroticism & 50 & 2.64 & 2.69 & 0.66 \\
BFI Openness & 50 & 3.60 & 3.55 & 0.51 \\
\hline
\end{tabular}




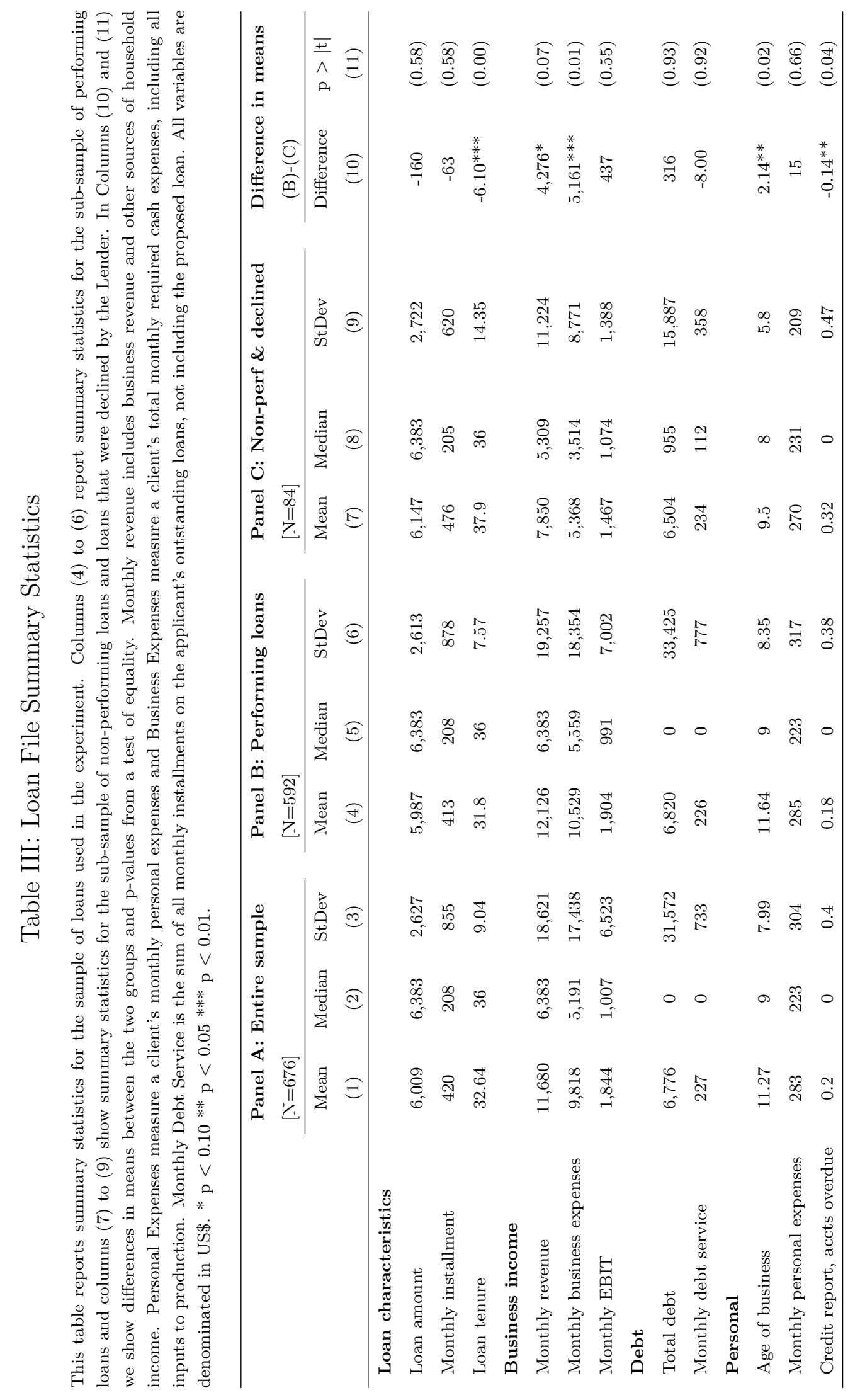




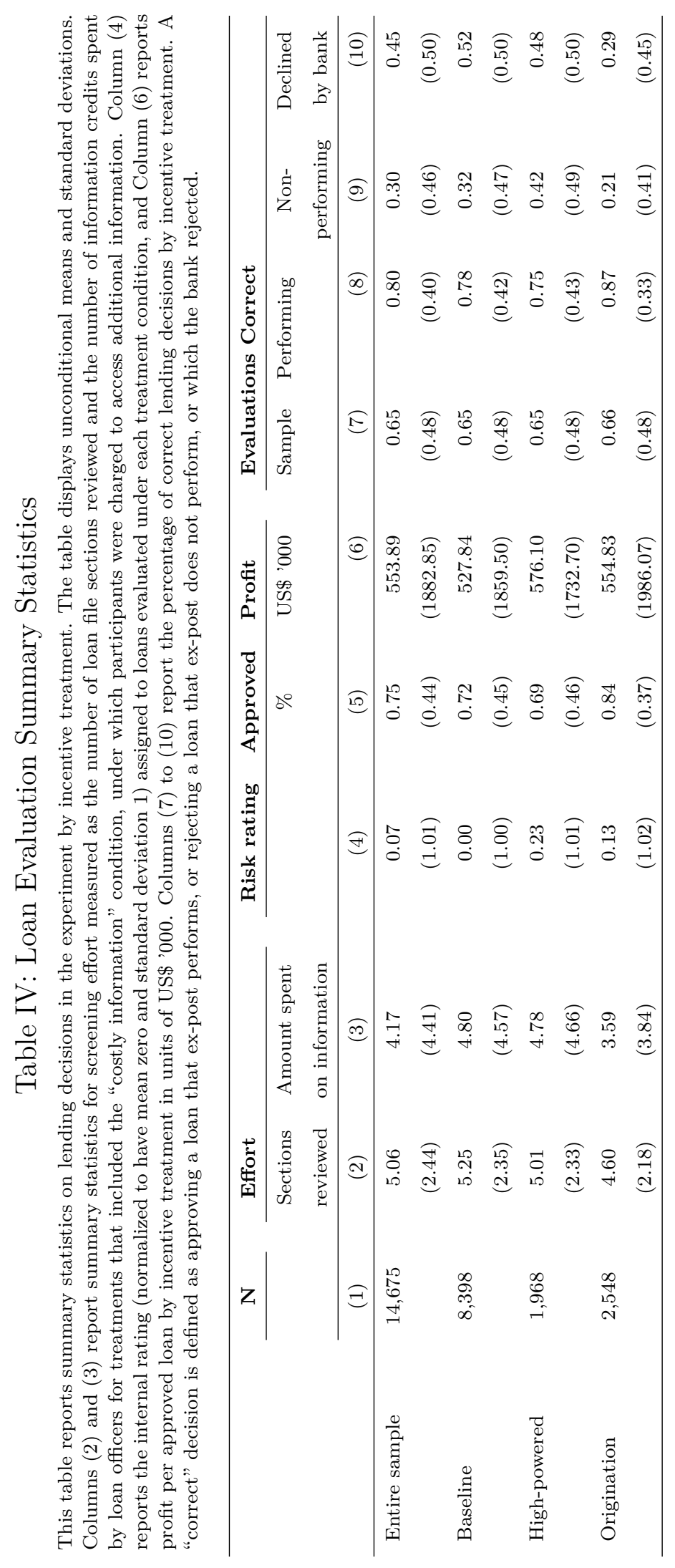




\section{Table V: The Effect of Incentives on Effort}

This table reports treatment effects of performance pay on screening effort. Each column reports results from a separate regression. The omitted treatment category is the low-powered baseline incentive. The dependent variable in Column (1) and (2) is number of sections of the loan file viewed; the dependent variable in Columns (3) and (4) is the number of loan file sections reviewed when loan officers were required to pay for additional information. The regressions in Columns (1) and (2) include the entire sample, while Columns (3) and (4) limit the data to evaluations to the "costly information setting." All regressions include a lab fixed effect, randomization stratum and week fixed effects, as well as dummies to control for treatment conditions not reported in this table.

Loan officer controls include age, seniority, rank, education, and indicators for branch manager and business experience. Standard errors, in parentheses, are clustered at the loan officer $\times$ session level. * $\mathrm{p}<0.10 * * \mathrm{p}<0.05 * * * \mathrm{p}<0.01$.

\begin{tabular}{|c|c|c|c|c|}
\hline & \multirow{3}{*}{\multicolumn{2}{|c|}{$\begin{array}{l}\text { Free information } \\
\text { Loan file } \\
\text { sections reviewed }\end{array}$}} & \multirow{3}{*}{\multicolumn{2}{|c|}{$\begin{array}{l}\text { Costly information } \\
\text { Loan file } \\
\text { sections reviewed }\end{array}$}} \\
\hline & & & & \\
\hline & & & & \\
\hline & $(1)$ & $(2)$ & $(3)$ & $(4)$ \\
\hline \multicolumn{5}{|l|}{ Baseline, omitted } \\
\hline \multirow[t]{2}{*}{ High-powered } & $0.434^{*}$ & $0.400^{* * *}$ & $1.225^{* * *}$ & $0.794^{* * *}$ \\
\hline & $(0.23)$ & $(0.14)$ & $(0.42)$ & $(0.25)$ \\
\hline \multirow[t]{2}{*}{ Origination bonus } & 0.083 & 0.005 & -0.147 & -0.156 \\
\hline & $(0.22)$ & $(0.14)$ & $(0.40)$ & $(0.21)$ \\
\hline \multirow[t]{2}{*}{ Performance bonus low } & -0.059 & -0.133 & 0.550 & 0.131 \\
\hline & $(0.29)$ & $(0.21)$ & $(0.38)$ & $(0.22)$ \\
\hline \multirow[t]{2}{*}{ Performance bonus high } & -0.000 & 0.019 & 0.175 & -0.084 \\
\hline & $(0.32)$ & $(0.24)$ & $(0.32)$ & $(0.16)$ \\
\hline Loan fixed effects & No & Yes & No & Yes \\
\hline Loan officer fixed effects & No & Yes & No & Yes \\
\hline Loan officer controls & Yes & No & Yes & No \\
\hline Number of observations & 14,405 & 14,675 & 8,520 & 8,688 \\
\hline R-squared, adjusted & 0.232 & 0.689 & 0.271 & 0.725 \\
\hline
\end{tabular}




\section{Table VI: The Effect of Incentives on Risk-Assessment}

This table reports the effect of performance pay on loan officers' subjective assessment of credit risk. Each column shows results from a separate regression. The omitted treatment category is the low-powered baseline incentive. The dependent variable in regressions (1) and (2) is the overall risk rating, standardized to have mean zero. The dependent variable in Columns (3) and (4) is the normalized sub-rating for all categories that pertain to the personal risk of a potential applicant. In Columns (5) and (6) the dependent variable is the normalized sub-rating for all rating categories that pertain to the business, management and financial risk of a loan applicant. All regressions include a lab fixed effect, randomization stratum and week fixed effects, as well as dummies to control for treatment conditions not reported in this table. Loan officer controls include age, seniority, rank, education, and indicators for branch manager and business experience. Standard errors are clustered at the loan officer $\times$ session level. ${ }^{*} \mathrm{p}<0.10{ }^{* *} \mathrm{p}<0.05^{* * *} \mathrm{p}<0.01$.

\begin{tabular}{|c|c|c|c|c|c|c|}
\hline & \multicolumn{6}{|c|}{ Internal rating } \\
\hline & \multicolumn{2}{|c|}{ Overall rating } & \multicolumn{2}{|c|}{$\begin{array}{l}\text { Personal and } \\
\text { management risk }\end{array}$} & \multicolumn{2}{|c|}{$\begin{array}{l}\text { Business and } \\
\text { financial risk }\end{array}$} \\
\hline & (1) & (2) & (3) & (4) & (5) & (6) \\
\hline \multicolumn{7}{|l|}{ Baseline, omitted } \\
\hline \multirow[t]{2}{*}{ High-powered } & 0.029 & 0.006 & 0.011 & -0.001 & 0.054 & 0.02 \\
\hline & $(0.09)$ & $(0.04)$ & $(0.09)$ & $(0.04)$ & $(0.09)$ & $(0.04)$ \\
\hline \multirow[t]{2}{*}{ Origination bonus } & $0.144^{*}$ & 0.006 & $0.130^{*}$ & -0.015 & $0.156^{* *}$ & 0.021 \\
\hline & $(0.08)$ & $(0.04)$ & $(0.08)$ & $(0.04)$ & $(0.08)$ & $(0.04)$ \\
\hline Loan fixed effects & No & Yes & No & Yes & No & Yes \\
\hline Loan officer fixed effects & No & Yes & No & Yes & No & Yes \\
\hline Loan officer controls & Yes & No & Yes & No & Yes & No \\
\hline Number of observations & 14,405 & 14,675 & 14,405 & 14,675 & 14,405 & 14,675 \\
\hline R-squared, adjusted & 0.151 & 0.640 & 0.142 & 0.644 & 0.161 & 0.626 \\
\hline
\end{tabular}




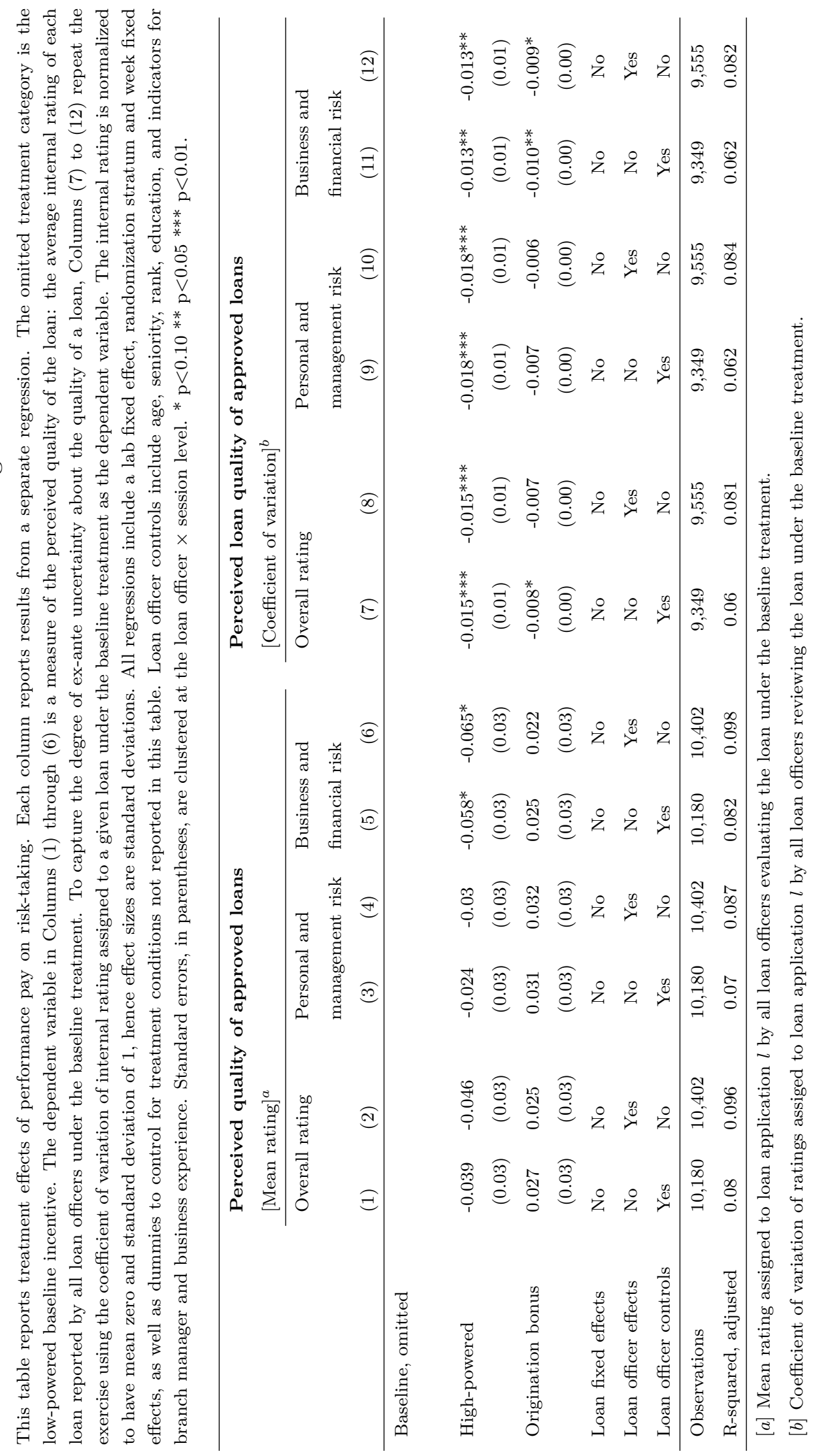



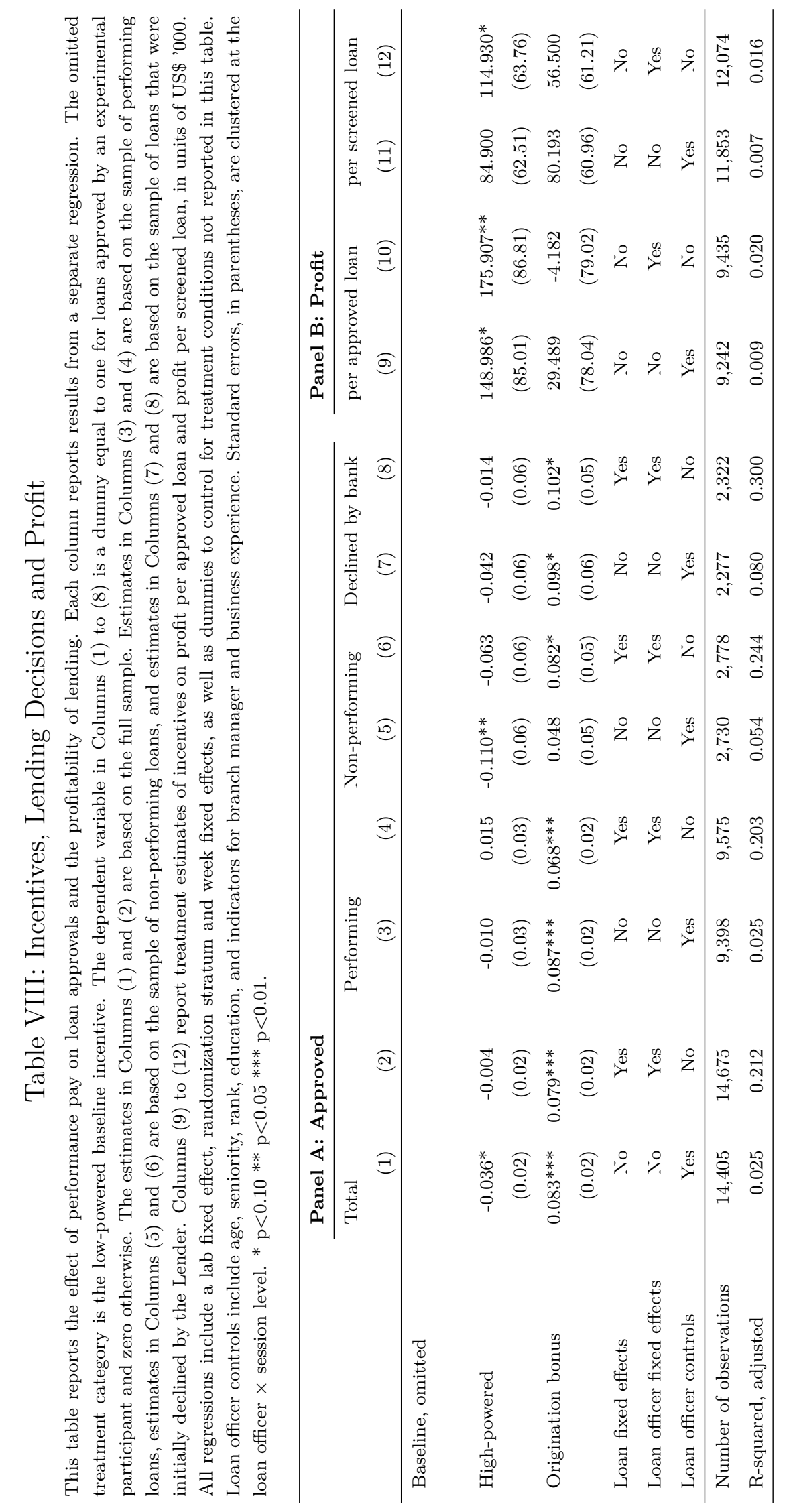


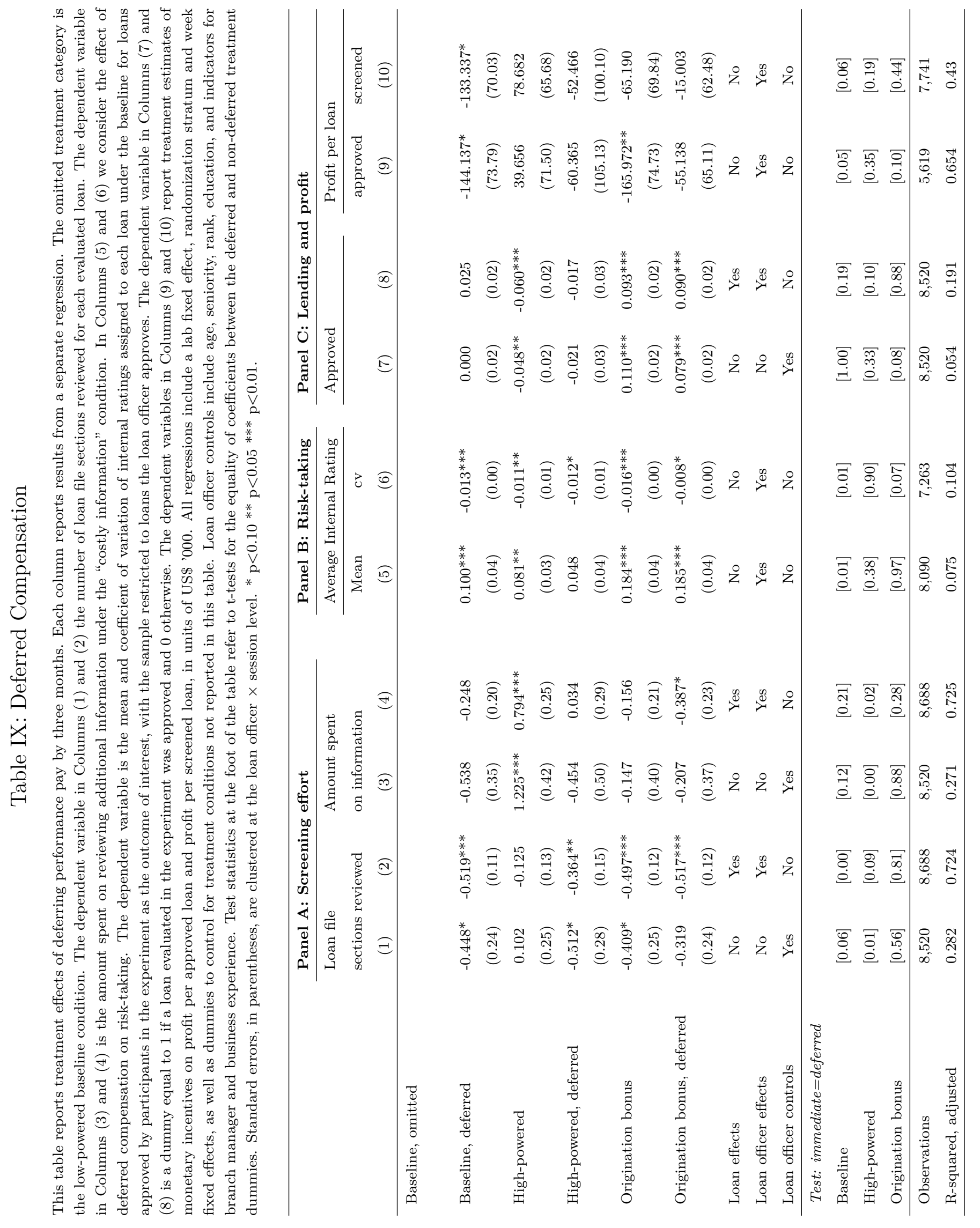




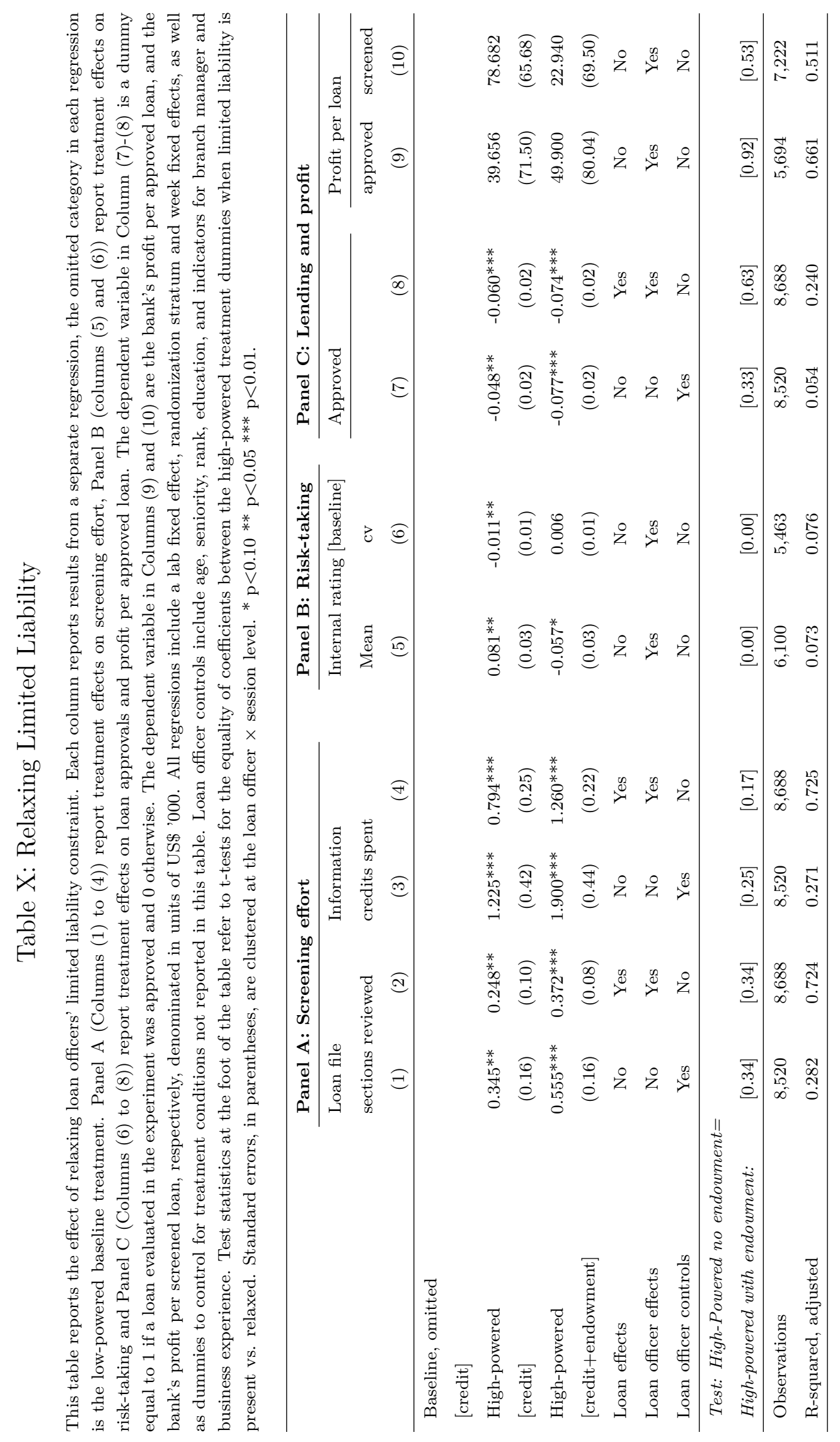




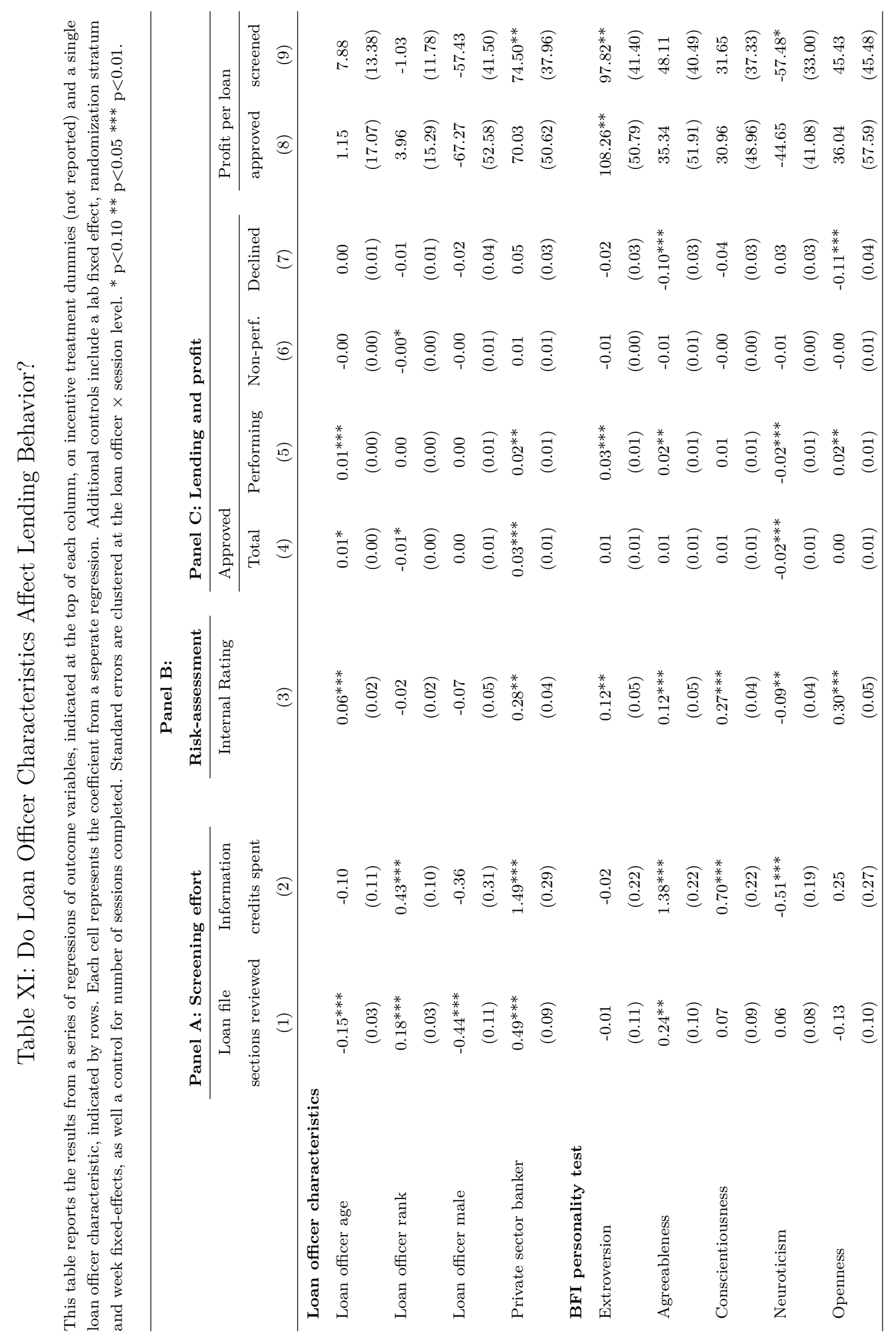




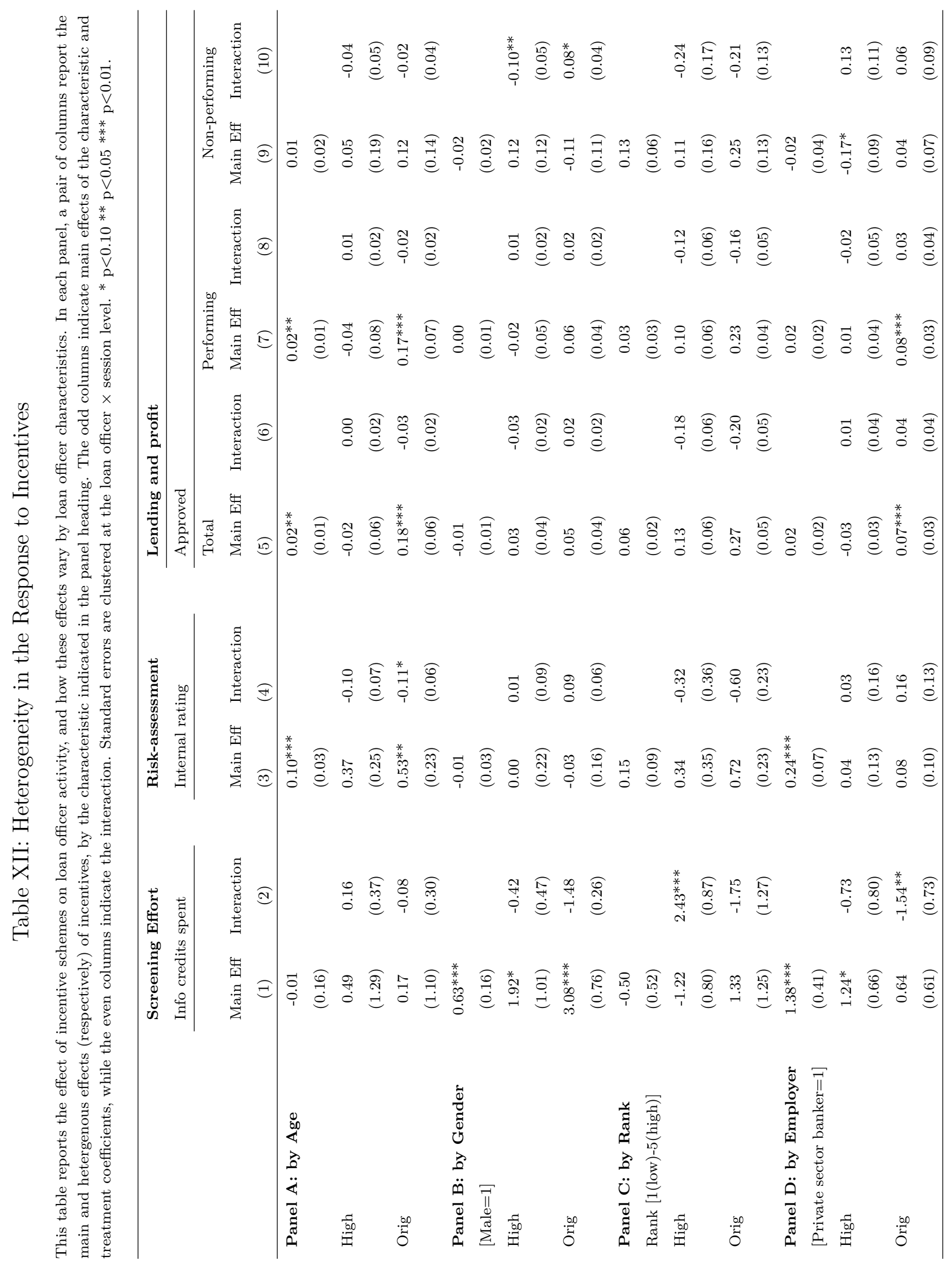




\section{Supplementary Appendix}




\section{A Data Appendix}

\section{Table OA.I: Description of Variables}

\begin{tabular}{|c|c|}
\hline Variable & Description \\
\hline $\begin{array}{l}\text { Number of loan file sections } \\
\text { reviewed }\end{array}$ & $\begin{array}{l}\text { Number of loan file sections reviewed out of a total of } 10 \text { sections: borrower profile, } \\
\text { application form, documentation list, deviations from financial ratios, income state- } \\
\text { ment balance sheet, site visit report (residence), site visit report (business), trade } \\
\text { reference check and credit bureau report, if available. }\end{array}$ \\
\hline Amount spent on information & $\begin{array}{l}\text { Number of Rupees spent (from a maximum of 18) per evaluated loan file. Only defined } \\
\text { when loan officers were charged for non-basic loan file sections. }\end{array}$ \\
\hline Internal rating & $\begin{array}{l}\text { Internal rating assigned to loan } l \text { by loan officer } i \text {. This measure is normalized by } \\
\text { subtracting the mean of the "control group," and dividing by the standard deviation } \\
\text { of the "control group." The control group is defined as those receiving low-powered } \\
\text { incentives }[20,0,10]\end{array}$ \\
\hline Personal and management risk & $\begin{array}{l}\text { Sum of all sub-components of the internal rating pertaining to the applicant's personal } \\
\text { and management risk, normalized as described above. }\end{array}$ \\
\hline Business and financial risk & $\begin{array}{l}\text { Sum of all sub-components of the internal rating pertaining to the applicant's business } \\
\text { and financial risk, normalized as described above. }\end{array}$ \\
\hline Overall rating (baseline mean) & $\begin{array}{l}\text { Mean of all risk ratings assigned to loan } l \text { in all evaluations under the "Baseline" } \\
\text { treatment. }\end{array}$ \\
\hline $\begin{array}{l}\text { Personal and management risk } \\
\text { (baseline mean) }\end{array}$ & $\begin{array}{l}\text { Mean of all risk ratings capturing personal and management risk, assigned to loan } l \\
\text { in all evaluations under the "Baseline" treatment. }\end{array}$ \\
\hline $\begin{array}{l}\text { Business and financial risk } \\
\text { (baseline mean) }\end{array}$ & $\begin{array}{l}\text { Mean of all risk ratings capturing business and financial risk, assigned to loan } l \text { in all } \\
\text { evaluations under the "Baseline" treatment. }\end{array}$ \\
\hline Approved & Dummy equal to 1 if a loan evaluated in the experiment was approved. \\
\hline Profit per approved loan & $\begin{array}{l}\text { Profit per approved loan from the viewpoint of the lender, measured as the discounted } \\
\text { stream of payments and origination fee minus the initial disbursement amount. Loans } \\
\text { turned down in the experiment are excluded. }\end{array}$ \\
\hline Profit per screened loan & $\begin{array}{l}\text { Profit per approved loan from the viewpoint of the lender, measured as the discounted } \\
\text { stream of payments and origination fee minus the initial disbursement amount. For } \\
\text { loans turned down in the experiment, the profit is equal to } 0 .\end{array}$ \\
\hline
\end{tabular}




\section{B Appendix Tables}

\section{Table OA.I: Test of Random Assignment}

This table presents a test of random assignment across the four main treatments. We regress treatment dummies on demographic variables, controlling for randomization strata, lab and week fixed effects. Age is the loan officer's age in years, Male is a dummy variable taking a value of 1 if the participant is male. Rank is the loan officer's level of seniority in the bank. Experience is the number of years the loan officer has been employed by the bank. Branch Manager is a dummy variable indicating whether the participant has ever served as a branch manager. ${ }^{*} \mathrm{p}<0.10^{* *} \mathrm{p}<0.05^{* * *} \mathrm{p}<0.01$.

\begin{tabular}{lrr}
\hline & Incentive Treatment & \\
\cline { 2 - 3 } & High-powered & Origination bonus \\
\hline Male & $(1)$ & -0.017 \\
Age & $(0.006$ & $(0.03)$ \\
& -0.002 & -0.001 \\
Education [Master's degree] & $(0.002)$ & $(0.002)$ \\
& -0.031 & 0.014 \\
Experience [Years] & $(0.019)$ & $(0.020)$ \\
& 0.002 & 0.001 \\
Rank [1 Lowest - 5 Highest] & $(0.001)$ & $(0.001)$ \\
& -0.005 & -0.009 \\
Branch manager experience & $(0.008)$ & $(0.008)$ \\
& -0.007 & -0.012 \\
& $(0.023)$ & $(0.024)$ \\
\hline Number of observations & 9,268 & 9,806 \\
\hline
\end{tabular}




\section{Table OA.II: Test for Learning During the Experiment}

This table presents a formal test for the presence of learning effects during the experiment. The dependent variable in column (1) is a dummy variable taking on a value of one for a correct lending decision, defined as approving a performing loan or declining a non-performing loan. The dependent variable in column (2) is the profit per loan for the sample of approved loans, denominated in US\$ '000, The dependent variable in column (3) is the profit per loans for the total sample of screened loans in units of US\$ '000. ${ }^{*} \mathrm{p}<0.10 * * \mathrm{p}<0.05 * * * \mathrm{p}<0.01$.

\begin{tabular}{|c|c|c|c|}
\hline & \multirow{2}{*}{$\begin{array}{l}\text { Lending decisions } \\
\text { correct }\end{array}$} & \multicolumn{2}{|c|}{ Profit per loan } \\
\hline & & approved & screened \\
\hline & $(1)$ & $(2)$ & (3) \\
\hline Number of experimental & $-0.002^{*}$ & 0.003 & -0.003 \\
\hline sessions completed & $(0.00)$ & $(0.00)$ & $(0.00)$ \\
\hline Loan fixed effects & Yes & No & No \\
\hline Loan officer fixed effects & Yes & Yes & Yes \\
\hline Number of observations & 14,675 & 9,357 & 13,084 \\
\hline R-squared & 0.322 & 0.652 & 0.415 \\
\hline
\end{tabular}




\section{Table OA.III: Predictive Content of Internal Ratings}

This table presents evidence on the predictive content of internal ratings. The dependent variable in column (1) is a dummy equal to 1 if a loan was approved by the reviewing loan officer and 0 otherwise. The dependent variable in column (2) is a dummy equal to 1 if a loan performed and 0 otherwise. In column (3) the dependent variable is the profit per loan of approved loans, denominated in units of US\$ '000. The dependent variable in column (4) is the profit per screened loan, denominated in units of US\$ '000. Each regression includes controls for the incentive treatment conditions and the number of experimental sessions completed by the reviewing loan officer. ${ }^{*} \mathrm{p}<0.10 * * \mathrm{p}<0.05 * * *$ $\mathrm{p}<0.01$

\begin{tabular}{|c|c|c|c|c|}
\hline & \multirow{2}{*}{$\begin{array}{l}\text { Lending } \\
\text { Approved=1 } \\
(1)\end{array}$} & \multirow{2}{*}{$\begin{array}{l}\text { Performance } \\
\text { Performing }=1 \\
(2)\end{array}$} & \multicolumn{2}{|c|}{ Profit per loan } \\
\hline & & & $\begin{array}{c}\text { approved } \\
(3)\end{array}$ & $\begin{array}{c}\text { screened } \\
(4)\end{array}$ \\
\hline \multicolumn{5}{|l|}{ Panel A: Final Rating } \\
\hline Log internal rating & $\begin{array}{c}1.348^{* * *} \\
(0.04)\end{array}$ & $\begin{array}{c}0.322^{* * *} \\
(0.03)\end{array}$ & $\begin{array}{c}0.659^{* * *} \\
(0.19)\end{array}$ & $\begin{array}{r}0.305^{* * *} \\
(0.05)\end{array}$ \\
\hline Number of observations & 13,979 & 13,979 & 8,834 & 12,411 \\
\hline R-squared & 0.443 & 0.064 & 0.03 & 0.024 \\
\hline \multicolumn{5}{|c|}{ Panel B: Personal and Management Risk } \\
\hline Log internal rating & $1.159^{* * *}$ & $0.279 * * *$ & $0.476^{* * *}$ & $0.251^{* * *}$ \\
\hline Personal and management risk & $(0.04)$ & $(0.03)$ & $(0.17)$ & $(0.06)$ \\
\hline Number of observations & 13979 & 13979 & 8834 & 12,411 \\
\hline R-squared & 0.368 & 0.061 & 0.03 & 0.023 \\
\hline \multicolumn{5}{|c|}{ Panel C: Business and Financial Risk } \\
\hline Log internal rating & $1.265^{* * *}$ & $0.318^{* * *}$ & $0.572^{* * *}$ & $0.282^{* * *}$ \\
\hline Business and financial risk & $(0.04)$ & $(0.02)$ & $(0.18)$ & $(0.05)$ \\
\hline Number of observations & 13,979 & 13,979 & 8,834 & 12,411 \\
\hline R-squared & 0.439 & 0.066 & 0.03 & 0.024 \\
\hline Loan fixed effects & No & No & No & No \\
\hline Loan officer fixed effects & Yes & Yes & Yes & Yes \\
\hline
\end{tabular}




\section{Table OA.IV: The Effect of Incentives on Effort}

This table reports treatment effects of performance pay on screening effort. Each column reports results from a separate regression. The omitted treatment category is the low-powered baseline incentive. The dependent variable in column (1) and (2) is number of sections of the loan file viewed; the dependent variable in Columns (3) and (4) is the number of loan file sections reviewed when loan officers were required to pay for additional information. The regressions in Columns (1) and (2) include the entire sample, while Columns (3) and (4) limit the data to evaluations to the "costly information setting." All regressions include a lab fixed effect, randomization stratum and week fixed effects, as well as dummies to control for treatment conditions not reported in this table. Loan officer controls include age, seniority, rank, education, and indicators for branch manager and business experience. Standard errors, in parentheses, are clustered at the loan officer $\times$ session level. ${ }^{*} \mathrm{p}<0.10^{* *} \mathrm{p}<0.05^{* * *} \mathrm{p}<0.01$.

\begin{tabular}{|c|c|c|c|c|}
\hline & \multirow{2}{*}{\multicolumn{2}{|c|}{$\begin{array}{l}\text { Free information } \\
\text { Loan file } \\
\text { sections reviewed }\end{array}$}} & \multirow{2}{*}{\multicolumn{2}{|c|}{$\begin{array}{l}\text { Costly information } \\
\text { Loan file } \\
\text { sections reviewed }\end{array}$}} \\
\hline & & & & \\
\hline & (1) & $(2)$ & (3) & $(4)$ \\
\hline \multicolumn{5}{|l|}{ Baseline, omitted } \\
\hline \multirow[t]{2}{*}{ High-powered } & $0.488^{*}$ & $0.332^{* *}$ & $1.225^{* * *}$ & $0.794^{* * *}$ \\
\hline & $(0.28)$ & $(0.15)$ & $(0.42)$ & $(0.25)$ \\
\hline \multirow[t]{2}{*}{ Origination bonus } & 0.125 & -0.135 & -0.147 & -0.156 \\
\hline & $(0.28)$ & $(0.16)$ & $(0.40)$ & $(0.21)$ \\
\hline \multirow[t]{2}{*}{ Performance bonus low } & -0.054 & -0.101 & 0.550 & 0.131 \\
\hline & $(0.29)$ & $(0.21)$ & $(0.38)$ & $(0.22)$ \\
\hline \multirow[t]{2}{*}{ Performance bonus high } & -0.018 & 0.080 & 0.175 & -0.084 \\
\hline & $(0.32)$ & $(0.25)$ & $(0.32)$ & $(0.16)$ \\
\hline Loan fixed effects & No & Yes & No & Yes \\
\hline Loan officer fixed effects & No & Yes & No & Yes \\
\hline Loan officer controls & Yes & No & Yes & No \\
\hline Number of observations & 5,885 & 5,987 & 8,520 & 8,688 \\
\hline R-squared, adjusted & 0.232 & 0.689 & 0.271 & 0.725 \\
\hline
\end{tabular}




\section{Table OA.V: The Effect of Incentives on Risk-Assessment}

This table reports the effect of performance pay on loan officers' subjective assessment of credit risk. Each column shows results from a separate regression. The omitted treatment category is the low-powered baseline incentive. The dependent variable in regressions (1) and (2) is the overall risk rating, standardized to have mean zero. The dependent variable in Columns (3) and (4) is the normalized sub-rating for all categories that pertain to the personal risk of a potential applicant. In Columns (5) and (6) the dependent variable is the normalized sub-rating for all rating categories that pertain to the business, management and financial risk of a loan applicant. All regressions include a lab fixed effect, randomization stratum and week fixed effects, as well as dummies to control for treatment conditions not reported in this table. Loan officer controls include age, seniority, rank, education, and indicators for branch manager and business experience. Standard errors are clustered at the loan officer $\times$ session level. ${ }^{*} \mathrm{p}<0.10^{* *} \mathrm{p}<0.05 * * * \mathrm{p}<0.01$.

\begin{tabular}{|c|c|c|c|c|c|c|}
\hline & \multicolumn{6}{|c|}{ Internal risk-rating } \\
\hline & \multicolumn{2}{|c|}{ Overall rating } & \multicolumn{2}{|c|}{$\begin{array}{l}\text { Personal and } \\
\text { management risk }\end{array}$} & \multicolumn{2}{|c|}{$\begin{array}{l}\text { Business and } \\
\text { financial risk }\end{array}$} \\
\hline & $(1)$ & $(2)$ & $(3)$ & $(4)$ & $(5)$ & $(6)$ \\
\hline \multicolumn{7}{|l|}{ Baseline, omitted } \\
\hline \multirow[t]{2}{*}{ High-powered } & 0.029 & 0.006 & 0.011 & -0.001 & 0.054 & 0.02 \\
\hline & $(0.09)$ & $(0.04)$ & $(0.09)$ & $(0.04)$ & $(0.09)$ & $(0.04)$ \\
\hline \multirow[t]{2}{*}{ Origination bonus } & $0.144^{*}$ & 0.006 & $0.130 *$ & -0.015 & $0.156^{* *}$ & 0.021 \\
\hline & $(0.08)$ & $(0.04)$ & $(0.08)$ & $(0.04)$ & $(0.08)$ & $(0.04)$ \\
\hline \multirow[t]{2}{*}{ Performance bonus low } & 0.044 & $0.157^{* * *}$ & 0.024 & $0.141^{* *}$ & 0.055 & $0.142^{* *}$ \\
\hline & $(0.11)$ & $(0.06)$ & $(0.11)$ & $(0.06)$ & $(0.11)$ & $(0.06)$ \\
\hline \multirow[t]{2}{*}{ Performance bonus high } & $0.267 * *$ & $0.298^{* * *}$ & $0.247^{* *}$ & $0.285^{* * *}$ & $0.266^{* *}$ & $0.275^{* * *}$ \\
\hline & $(0.12)$ & $(0.06)$ & $(0.12)$ & $(0.06)$ & $(0.11)$ & $(0.06)$ \\
\hline Loan fixed effects & No & Yes & No & Yes & No & Yes \\
\hline Loan officer fixed effects & No & Yes & No & Yes & No & Yes \\
\hline Loan officer controls & Yes & No & Yes & No & Yes & No \\
\hline Number of observations & 14,405 & 14,675 & 14,405 & 14,675 & 14,405 & 14,675 \\
\hline R-squared, adjusted & 0.151 & 0.64 & 0.142 & 0.644 & 0.161 & 0.626 \\
\hline
\end{tabular}




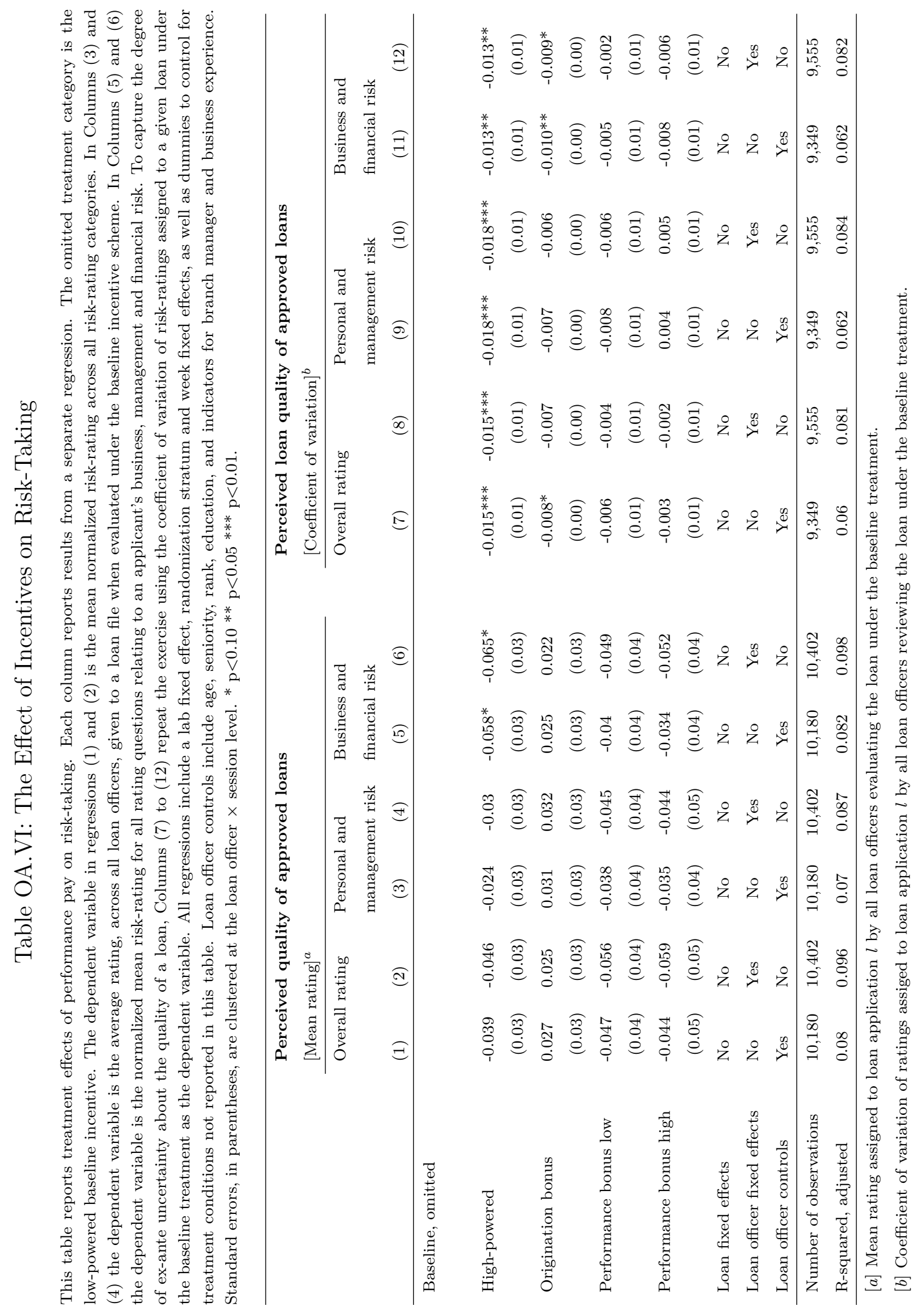



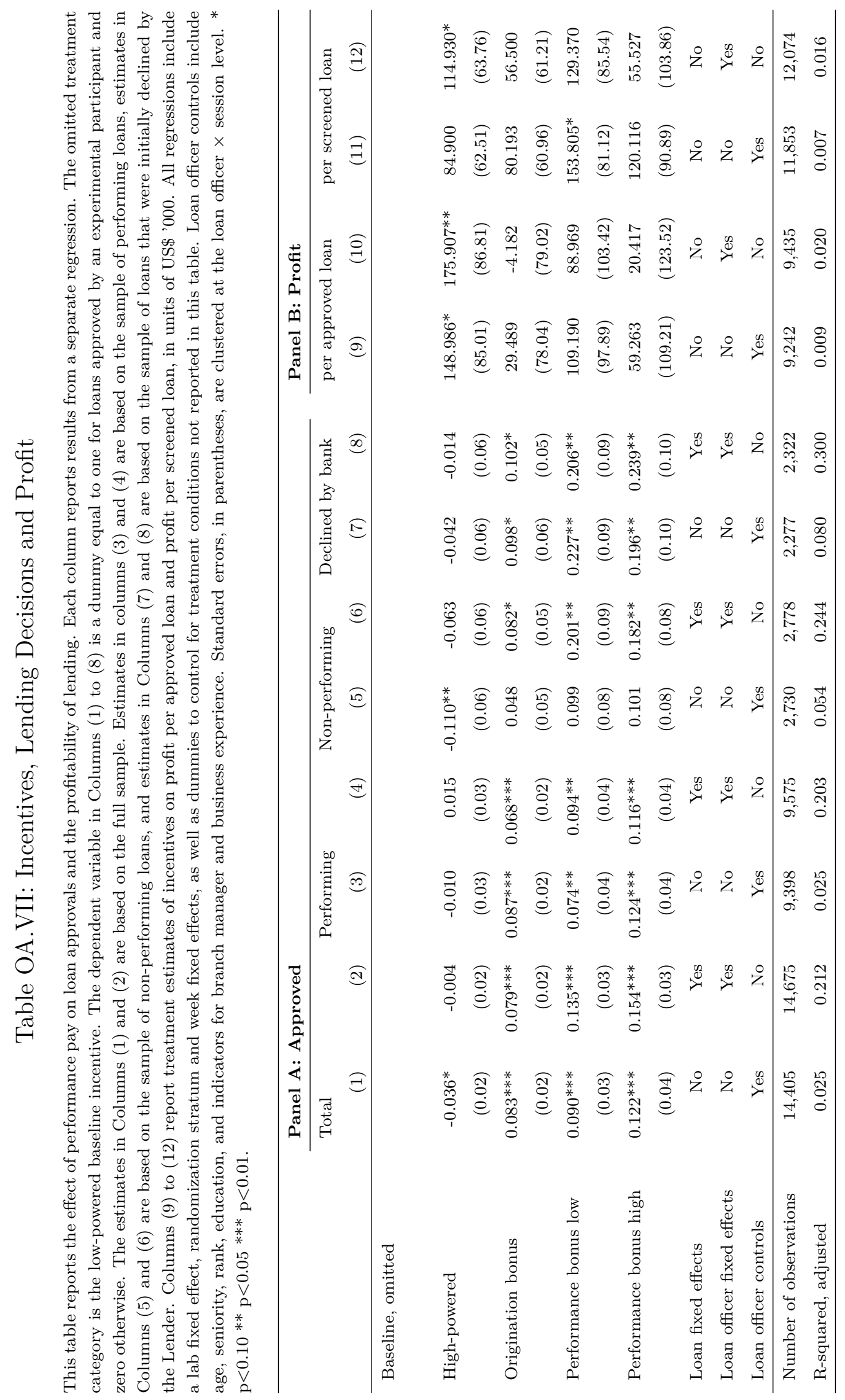